Maurice A. Deane School of Law at Hofstra University Scholarly Commons at Hofstra Law

Hofstra Law Faculty Scholarship

$5-2000$

\title{
Women and Globalization: The Failure and Postmodern Possibilities of International Law
}

Barbara Stark

Maurice A. Deane School of Law at Hofstra University

Follow this and additional works at: https://scholarlycommons.law.hofstra.edu/faculty_scholarship

\section{Recommended Citation}

Barbara Stark, Women and Globalization: The Failure and Postmodern Possibilities of International Law, 33 Vand. J. Transnat'l L. 503 (2000)

Available at: https://scholarlycommons.law.hofstra.edu/faculty_scholarship/171

This Article is brought to you for free and open access by Scholarly Commons at Hofstra Law. It has been accepted for inclusion in Hofstra Law Faculty Scholarship by an authorized administrator of Scholarly Commons at Hofstra Law. For more information, please contact lawcls@hofstra.edu. 


\title{
VANDERBILT JOURNAL \\ OF \\ TRANSNATIONAL LAW
}

\section{Women and Globalization: The Failure and Postmodern Possibilities of International Law}

\author{
Barbara Stark
}

\begin{abstract}
This Article examines the role of international law, particularly human rights law, as it relates to the process of globalization and its effects on women. Initially, the Article sets the stage by describing the course of globalization and the dramatic impact it has had on the world economy. The Author next examines the multiple and contradictory consequences of globalization for women.

The Article approaches this analysis from two perspectives. First, from a "classic perspective," the Author contends that international law is the only legal system with the potential to regulate the principal agents of globalizationmultinational corporations, banks and investment firms, and international organizations-and to insist that they respect

* Professor of Law, University of Tennessee College of Law. B.A., Cornell; J.D., N.Y.U.; LL.M., Columbia. Early versions of this Article were presented at the 1999 Annual Meeting of the American Society of International Law and a Faculty Colloquium at the University of Tennessee. Thanks to all for their helpful comments, especially Tom Galligan and Dwight Aarons, to Fran Ansley for her careful reading of an earlier draft, to the College of Law for its generous support, and to Angela O'Neal for her research assistance. I am also indebted to Pat $\mathrm{McNeil}$ for her heroic efforts with the manuscript.
\end{abstract}


women's human rights. Unfortunately, international law currently lacks the legal machinery to do so and the political will to create it.

From a "postmodern perspective," in contrast, the Author asserts that international law is not a system at all. Rather, it is better understood as a superstore, a warehouse of treaties, customs, institutions, and norms. From this perspective, international human rights law may be viewed as a source of norms that women can draw upon to support a virtually endless range of ad hoc strategies. Although a postmodern conception of international law looks with skepticism on the aspirations of the classic conception, it may in fact be more effective in realizing some of those aspirations in the context of globalization.

\section{TABLE OF CONTENTS}

I. INTRODUCTION ................................................ 506

II. WOMEN AND GLOBALIZATION ................................. 509

A. Globalization ........................................... 509

1. The Free Flow of Capital and

Free Trade .................................... 510

2. Culture ...................................... 515

a. The Lexus and the

Olive Tree ............................. 517

b. The Intercontinental

Hotel .................................... 518

B. Women in the Global Economy................... 520

1. Data ......................................... 520

a. An Overview: Statistics .......... 520

b. A Closer Look: The Feminization of Labor ............. 522

i. Wage Differentials............ 523

ii. Women's Work ................. 523

iii. Lack of Data ................... 526

2. Snapshots................................... 527

a. A Teenager in the
Maquiladoras........................ 527

b. A Woman and Her Children in the Moscow Subway............ 528

c. A Woman Leaving Her Children in Central Park .................................... 529

d. A Young Girl in Thailand......... 530

III. The FAILURE OF ClasSic INTERNATIONAL LAW............ 531 
A. International Human Rights Law.............. 532

1. The System ............................... 532

2. Economic Rights ......................... 535

a. On the State Level ................ 535

b. Non-State Actors.................. 537

i. International

Organizations (IOs) ......... 537

ii. Multinational

Corporations (MNCs) ........ 538

iii. Investment Firms............ 540

B. The Roles of Lawyers............................. 541

1. Theory: Better, Clearer, More.......... 542

2. Practice: Using the Law to

Represent Clients.......................... 543

C. The Position of Women .............................. 544

1. Theory: "Equal" to Men................... 544

2. Practice: A "Better" World for

Our Daughters............................ 545

IV. THE POSSIBILITIES OF POSTMODERN INTERNATIONAL

LAW........................................................... 546

A. Postmodern International Law.................... 546

1. Fragmentation and Discontinuity .... 547

2. Incredulity Toward Metanarratives .. 548

3. The Cultural Logic of Late

Capitalism ................................... 553

4. The Bottom Line........................... 554

B. The Roles of Women.............................. 556

1. Fragmentation and Discontinuity:

2. Incredulity Toward Metanarratives:

3. The Cultural Logic of Late

Capitalism: Women as Workers/

Consumers/Investors..................... 559

C. The Roles of Lawyers............................. 561

1. Practice...................................... 561

a. Access to the Superstore........ 561

b. Representing Clients.............. 562

2. Deconstructing Theory .................. 562

V. A PARADOX? ................................................. 565

A. From a Classic Perspective....................... 565

B. From a Postmodern Perspective: The
Politics of Paradox................................. 567

VI. CONCLUSION................................................. 568 
Once more the storm is howling, and half hid

Under this cradle-hood and coverlid

My child sleeps on. There is no obstacle

But Gregory's wood and one bare hill

Whereby the haystack- and roof-levelling wind,

Bred on the Atlantic, can be stayed;

And for an hour I have walked and prayed

Because of the great gloom that is in my mind. ${ }^{1}$

-William Butler Yeats, A Prayer for my Daughter

\section{INTRODUCTION}

National laws play a significant role in promoting globalization ${ }^{2}$ - that is, the increasingly free flow of capital throughout the world, especially since end of the Cold World. ${ }^{3}$ There are few contexts in which international law plays a more important role-or a more visible one-than the international economic institutions that subsidize globalization (such as the International Monetary Fund (IMF) and the World Bank), the treaties that structure trade relations (such as North American

1. The Variorum Edition of the Poems of W. B. Yeats 403 (Peter allt \& Russell K. Alspach eds., 1957) [hereinafter VARIORUM EDITION]. Yeats, who insisted that his work be published in a specific order, placed this poem immediately after the better-known The Second Coming. There, he apprehended "mere anarchy is loosed upon the world." Id. at 402 . Here, for the sake of his beloved infant daughter, he struggles to grapple with it in a constructive way. This Article attempts to grapple with a similar apprehension for a similar reason. Yeats had a lifelong fascination with the role of gender and gender roles, and a substantial body of criticism demonstrates his continuing importance to feminists. See, e.g., YEATS AND WOMEN (Deirdre Toomey ed., 2d ed. 1997); ELIZABETH BUTLER CULlingFoRd, GENDER AND HistoRY IN YEATS'S LOVE POETRY (1993). Yeats also provides a useful window on globalization, since he is both an icon of Western culture and, as an Irish nationalist, one of the earliest and most outspoken opponents of the British Empire. As Edward Said has explained, "Yeats is a poet who belongs to a tradition . . . of the colonial world ruled by European imperialism ... during the late nineteenth and early twentieth centuries-bringing to a climactic insurrectionary stage, the massive upheaval of anti-imperialis[m]." Edward W. Said, Yeats and Decolonization, in TERRY EAGLETON ET Al., NATIONALISM, COLONIALISM, AND LITERATURE 69-70 (1990). Finally, I draw on Yeats because, "[i]n order to articulate violations that are repressed in the dominant language-game, a change of style may be necessary." Martti Koskenniemi, Letter to the Editors of the Symposium, 93 AM. J. INT'L L. 351, 361 (1999).

2. As Saskia Sassen points out, for example, austerity policies "have to be run through national governments and reprocessed as national policies." SASKIA SASSEN, LOSING CONTROL? SOVEREIGNTY IN AN AGE OF GLOBALIZATION 107-08 n.36 (1996).

3. For a fuller definition, see infra Part II.A. (historical summary of the free flow of capital). 
Free Trade Agreement (NAFTA) and the World Trade Organization (WTO)), or the rapidly proliferating codes of conduct that attempt to bring labor standards into the process. Thus, globalization offers a particularly rich context in which to analyze and assess the role of international law at the millennium.

More specifically, the focus of this Article is the impact of globalization on women. Women are, of course, a large and diverse group, and the impact of globalization on women is complex and often contradictory. While a recent study by economists at the International Center for Research on Women concludes that "[w]omen have generally benefited from improvements in the world economy," Symposium describe "the overall negative effects of globalization on women."5 Everyone agrees, however, that "forces shaping global integration affect women differently." "For many women globalization has been a mixed blessing, ${ }^{7}$ and for some it has been a disaster. ${ }^{8}$

This Article analyzes the role of international law, particularly human rights law, in this phenomenon from two different perspectives, comparing their views of women and the roles each

4. Rekha Mehra \& Sarah Gammage, Trends, Countertrends, and Gaps in Women's Employment, 27 WORLD DEv. 533, 533 (1999). "[O]n all fronts there has been an improvement and, in fact, the speed at which labor markets in developing countries change has been much faster than the experience of industrialized countries would suggest." Zafiris Tzannatos, Women and Labor Market Changes in the Global Economy: Growth Helps, Inequalities Hurt and Public Policy Matters, 27 WORLD DEv. 551, 567 (1999). See also Susan Horton, Marginalization Revisited: Women's Market Work and Pay, and Economic Development, 27 WORLD DEV. 571, 571 (1999) (according to labor force surveys in middle income developing countries:

Women's participation rates in the market labor force have been increasing, women have shifted into white-collar occupations, and certain previously male-dominated occupations have become female-dominated (clerical work in Asia, for example). Women's relative pay has risen somewhat faster in Asia and Latin America than occurred during industrialization in the United States. Although inequalities remain, there is no evidence that women on average are being marginalized.);

Saskia Sassen, Toward a Feminist Analytics of the Global Economy, 4 IND. J. GLOBAL LEGAL STUD. 7, 10 (1996) (describing the "growing number of top level women professionals in global economic activities and in international relations").

5. Alfred C. Aman, Jr., Introduction: Feminism and Globalization: The Impact of the Global Economy on Women and Feminist Theory, 4 IND. J. GLOBAL LEGAL STUD. 1, 4 (1996).

6. Mehra \& Gammage, supra note 4, at 534.

7. See, e.g., Kenneth G. Dau-Schmidt, Dividing the Surplus: Will Globalization Give Women a Larger or Smaller Share of the Benefits of Cooperative Production? 4 IND. J. Giobal LEGAL STUD. 51, 56 (1996) (noting that "the effect of globalization on women will be both positive and negative").

8. See, e.g., Part II.B.2. 
assigns to the lawyers who seek to further women's interests. First, from the "classic perspective," international law is a coherent, albeit still evolving, system. In fact, it is the only legal system that exists on a scale capable of effectively promoting the human rights of women.9 Only international law has the potential to regulate the principal agents of globalization (the multinational corporations (MNCs)), ${ }^{10}$ the banks and investment firms, ${ }^{11}$ and the international organizations (IOs) ${ }^{12}$ (hereinafter referred to collectively as the Major Players) and to insist that they respect women's human rights. Unfortunately, international law currently lacks the legal machinery to do so and the political will to create it, so women and their lawyers must rely on national law, which is uneven at best, while simultaneously working to strengthen the international legal system.

From another perspective, however, international law is not a system at all. ${ }^{13}$ From a "postmodern perspective,"14 international law is best understood as a superstore, a warehouse of treaties, customs, international institutions and norms, as well as national laws intended to implement or to avoid them. From this

9. See generally David Weissbrodt \& Marci Hoffman, The Global Economy and Human Rights: A Selective Bibliography, 6 MINN. J. GLOBAL TRADE 189 (1997).

10. See, e.g., Zillah Eisenstein, Stop Stomping on the Rest of Us: Retrieving Publicness from the Privatization of the Globe, 4 IND. J. GLOBAL LEGAL STUD. 59, 66 (1996) (arguing that "[e]ven the United Nations acknowledges that transnational corporations are the central organizers of the world economy"); J. A. Lindgren Alves, The United Nations, Postmodernity, and Human Rights, 32 U.S.F. L. REV. 479, 480 (1998); Donna E. Arzt \& Igor I. Lukashuk, Participants in International Legal Relations, in INTERNATIONAL LAW: CLASSIC AND CONTEMPORARY READINGS 155, 176 n.42 (Charlotte Ku \& Paul F. Diehl eds., 1998).

Multinationals now account for about a third of world output and twothirds of world trade. Most significantly, around a quarter of world trade occurs within multinational corporations. In 1993, according to a United Nations survey, the combined output of multinationals was around $\$ 5.5$ trillion-roughly as much as that of the U.S. as a whole.

John Gray, False Dawn: The Delusions of Global Capitalism 62 (1998).

11. See, e.g., SASSEN, supra note 2, at xiv (describing the "economic citizenship" of global financial markets that have power over governments).

12. See generally CATHERINE CAUFIELD, MASTERS OF ILlUSION: THE WORLD BANK AND THE POVERTY OF NATIONS (1996) (criticizing the World Bank's development policies).

13. This does not preclude the possibility of intelligible systems within international law. See, e.g., Phillip R. Trimble, International Law, World Order, and Critical Legal Studies, 42 STAN. L. REV. 811 (1990).

14. Others have examined the relationship between postmodernism and international law. See, e.g., BOAVENTURA DE SOUSA SANTOS, TOWARD A NEW COMMON SENSE: LAW, SCIENCE AND POLITICS IN THE PARADIGMATIC TRANSITION (1995); RICHARD FALK, EXPLORATIONS AT THE EDGE OF TIME: THE PROSPECTS FOR WORLD ORDER (1992); Alves, supra note 10; Mark D. West, Japan and "Post-modern" Human Rights, LAW QUADRANGLE NOTES, Fall-Winter 1999, at 24. 
perspective, international human rights law, particularly economic rights law, may best be understood as a source of norms, useful in a variety of "performative roles."15 Women and their lawyers can draw upon economic rights law in a virtually endless range of such performative roles to influence, if not determine, the actions of the Major Players. ${ }^{16}$

This Article will be in four parts. Part II provides an overview of globalization and its multiple and contradictory consequences for women. Part III explains how classic international law has failed women in this context, while keeping their lawyers quite busy, by focusing first on the failure of economic rights law on the state level, and second on the failure of economic rights law to address the problem of non-state actors. Part IV shifts perspective to describe the possibilities of postmodern international law for women adversely affected by globalizationpossibilities that may still keep their lawyers busy, but which are likely to assign them less important roles. Part V explains why, paradoxically, a postmodern conception of international law, which looks with considerable skepticism on the aspirations of the classic conception, may in fact be more effective in realizing some of those aspirations in this context. ${ }^{17}$

\section{WOMEN AND GLOBALIZATION}

\section{A. Globalization}

"Globalization" refers to the free flow of capital and the removal of trade barriers between states, as well as to the accompanying cultural transformations and exchanges. The relationship between the globalization of capital and markets, on the one hand, and the globalization of culture, on the other, varies depending on the context. ${ }^{18}$ For present purposes, two

15. "Performative roles" include persuasion or justification, identification or organization of a political grouping, and motivational orientation. See, e.g., Pierre Schlag, Values, 6 YALE J. L. \& HuMAN. 219, 228 (1994).

16. See, e.g., Philip Alston, The UN's Human Rights Record: From San Francisco to Vienna and Beyond, in INTERNATIONAL LAW: CLASSIC AND CONTEMPORARY READINGS, supra note 10 , at 355,362 (calling for a "more probing, more selfconscious and more eclectic" approach to human rights).

17. See generally Koskenniemi, supra note 1, at $361 \mathrm{n} .15$ (explaining that the relationships between different legal methods and political orientation are "culturally embedded and not fixed; hence, stylistic associations may sometimes take surprising turns.").

18. Are we looking at Latin America or Southeast Asia? 1985 or 1995 ? What particular aspect of culture are we talking about? 
generalizations usually hold: (1) the former drives the latter, ${ }^{19}$ that is, the globalization of markets and capital fuels the globalization of culture including resistance to this globalization; and (2) both forms of globalization are in constant flux and are, therefore, unpredictable. ${ }^{20}$

\section{The Free Flow of Capital and Free Trade}

Globalization is the "constant revolutionizing of production" and the "endless disturbance of all social conditions." 21 It is "everlasting uncertainty."22 Everything "fixed and frozen" is "swept away" and "all that is solid melts into air."23 As these quotations from The Communist Manifesto, written 150 years ago, indicate, globalization is nothing new. In the 1320s, England, then a developing country, defaulted on loans to the Italian city state of Genoa. ${ }^{24}$ For most of Western history, ${ }^{25}$ capital has flowed freely. ${ }^{26}$

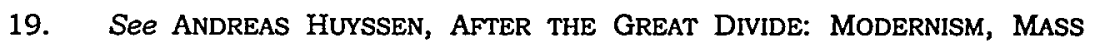
CULTURE, POSTMODERNISM 21 (1986) (describing how "twentieth century capitalism has 'reunified' economy and culture by subsuming the cultural under the economic, by reorganizing the body of cultural meanings and symbolic significations to fit the logic of the commodity."). The relationship between culture and capitalism has long inspired passionate debate. For a fascinating window into the intellectual history of the first half of the twentieth century, see ERNST BLOCH ET AL., AESTHETICS AND POLITICS (Ronald Taylor ed., 1977).

20. But see BUSINESS AND HUMAN RIGHTS: AN INTERDISCIPLINARY DISCUSSION HELD AT HARVARD LAW SCHOOL IN DECEMBER 1997, at 46 (remarks of Debora Spar) (Human Rights Program ed., 1999) [hereinafter Business AND HUMAN RIGHTS] ("What happens as investment goes into the underdeveloped countries? The data is very noisy .... Essentially, the correlation runs in the direction that you want to see it run: in places where you have higher levels of U.S. foreign investment, you have better conditions of human rights.").

21. Josef Joffe, One Dollar, One Vote, N.Y. TIMES, Apr. 25, 1999, § 7 (Book Review), at 14 (citing KARL MARX \& FREDERICK ENGELS, THE COMMUNIST MANIFESTO).

22. Id.

23. Id. Santos defines globalization as "the process by which a given local condition or entity succeeds in expanding its reach over the globe and, by doing so, develops the capacity to designate a rival social condition or entity as local." Boaventura de Sousa Santos, Oppositional Postmodernism and Globalizations, 23 L. \& SOC. INQUIRY 121, 135 (1998).

24. See Nicholas D. Kristof \& Edward Wyatt, Who Went Under in the World's Sea of Cash, N.Y. TIMES, Feb. 15, 1999, at A1.

25. "By the beginning of World War I, Europe and America held $85 \%$ of the earth's surface in some sort of colonial subjugation. This, I hasten to add, did not happen in a fit of absentminded whimsy or as a result of a distracted shopping spree." Said, supra note 1, at 69-71.

26. Not until the Great Depression did most governments impose constraints to prevent capital flight. See Nicholas D. Kristof \& David E. Sanger, How U.S. Wooed Asia to Let Cash Flow In, N.Y. TiMES, Feb. 16, 1999, at Al. In the 1960 s, the United States limited rights of citizens and corporations to invest oversees. See id. In the 1970 s and 1980 s, however, the free flow of capital again 
The end of the Cold War and developments in finance 27 and technology combined to qualitatively change the game during the past ten years. ${ }^{28}$ The failure of Soviet communism became the triumph of free market democracy, as formerly closed markets opened and capital poured in at a previously unimaginable rate. ${ }^{29}$ As a fund manager in Hong Kong observed, "[i]t's no longer the real economy driving the financial markets, but the financial markets driving the real economy. "30 In addition, the election of President Clinton in 1992 put a free market enthusiast in the White House. ${ }^{31}$ The world has never seen anything like the flow of capital during the eight years of his presidency. As then Deputy U.S. Secretary of the Treasury Lawrence H. Summers noted:

When history books are written 200 years from now about the last two decades of the 20th century, I am convinced that the end of the cold war will be the second story. The first story will be about the appearance of emerging markets-about the fact that developing countries where more than three billion people live have moved toward the market and seen rapid growth in incomes. ${ }^{32}$

Globalization has dramatically increased world income, but it has also increased the polarization between the "haves" and "have-nots." This is part of a longer term trend, beginning after World War II. As the United Nations Development Program (UNDP) summarizes:

began to look like a good idea. Presidents Reagan and Bush both supported free trade, for example, and thus contributed to the transformation of the global economy. See id.

27. "Securitization and the ascendance of finance generally have further stimulated the global circulation of capital and the search for investment opportunities worldwide .... SASSEN, supra note 2 , at 37.

28. See, e.g., Peter J. Spiro, New Players on the International Stage, 2 HOFSTRA L. \& POL'Y SYMP. 19, 21-22 (1997) (describing the revolution in global communications and its impact on financial systems).

29. "In a typical day the total amount of money changing hands in the world's foreign exchange markets alone is $\$ 1.5$ trillion-an eightfold increase since 1986 and an almost incomprehensible sum, equivalent to total world trade for four months." Kristof \& Wyatt, supra note 24 , at A1.

30. Id.

31. In 1991, then-Governor Bill Clinton met with Robert Rubin, the head of Goldman Sachs at the time, in the private dining room of the "21" Club in New York. Rubin, along with other Wall Street leaders, wanted to know whether the presidential hopeful understood the importance of opening Asian markets. Clinton won their support with his enthusiasm. See Kristof \& Sanger, supra note 26 , at $\mathrm{A1}$.

32. Kristof \& Wyatt, supra note 24, at A1. Summers is now U.S. Secretary of the Treasury. See generally Jodie T. Allen et al., Clinton's New Money Man: The Nation's Next Treasury Secretary Has a Hard Act to Follow, U.S. NEWS \& WORLD REP., May 24, 1999, at 44 (noting that Summers produced a study concluding that educating girls is the key factor in promoting economic development.). 
During the past five decades, world income increased sevenfold (in real GDP) and income per person more than tripled (in per capita GDP) [b]ut this gain has been spread very unequally-nationally and internationally-and the inequality is increasing. Between 1960 and 1991, the share of world income for the richest $20 \%$ of the global population rose from $70 \%$ to $85 \%$. Over the same period, all but the richest quintile saw their share of world income fall-and the meager share to the poorest $20 \%$ declined from $2.3 \%$ to $1.4 \% .^{33}$

While the tide is still rising, it is not taking all boats with it. Many of those in the leakiest, smallest boats, not surprisingly, are being swamped. Moreover, gross national product (GNP) is not a reliable indicator of human welfare. ${ }^{34}$ That is, even if boats are rising, their human cargo may be washed overboard. The risks are greater, furthermore, because globalization has increased both market volatility and market interdependence. In other words, markets are soaring to new highs and plunging to new lows, bouncing from one to the other faster-and less predictably-than ever before, and dragging others with them, sometimes with ruinous consequences.

As free trade has been extended to smaller countries with less regulatory infrastructure and experience with capital, ${ }^{35}$ this unprecedented capital flow often has wound up in incompetent and unsupervised hands. In 1996, for example, the Thai Minister of Justice accused his fellow cabinet members of taking $\$ 90$ million in bribes for bank licenses. ${ }^{36}$ In addition to widespread corruption and cronyism, wild investment schemes ${ }^{37}$ and a shaky economy contributed to the 1997 collapse of the Thai baht. ${ }^{38}$ But there were contributing factors outside of Thailand and beyond Thai control. Financial institutions played a critical role through unrestrained speculation and hedge funds. The G7,

33. HOLly SKLAR, CHAOS OR COMMUNiTy? SEEKING SOlutions, NOT SCAPEGOATS FOR BAD ECONOMICS 162 (1995) (citing U.N. DEV. PROGRAMME, 1994 HuMAN DEVELOPMENT REPORT 18, 26-27, 35 (1994). See also The Maastricht Guidelines on Violations of Economic, Social and Cultural Rights, 20 HuM. RTS. Q. 691, 691-92 (1998) [hereinafter Maastricht Guidelines]; Keith Bradsher, Gap in Wealth in U.S. Called Widest in West, N.Y. ThMES, Apr. 17, 1995, at A1.

34. For a clear explication of the limits of GNP, see Martha Nussbaum \& Amartya Sen, Introduction, in THE QUALITY OF LIFE 1 (Martha Nussbaum \& Amartya Sen eds., 1993) (explaining why "we also need, at the very least, to ask about the distribution of these resources, and what they do to people's lives .... We need to know about their health care and their medical services . . . education . . . labour ... political and legal privileges the citizens enjoy ... how family relations and relations between the sexes are structured.").

35. See Kristof \& Sanger, supra note 26 , at A1.

36. See id.

37. See, e.g., id. (describing the uninhabited ghost town of twenty-four skyscrapers surrounded by townhouses and shops in rural Thailand).

38. See Kristof \& Wyatt, supra note 24, at A1. 
the seven major industrialized states, remained oblivious to the looming disaster-despite Japan's warning ${ }^{39}$-and failed to address the emergency when it became impossible to ignore.

The collapse of the baht was quickly followed by the crash of the Indonesian economy, and repercussions spread even to economies that were doing everything right, like Brazil. ${ }^{40}$ From Southeast Asia to Eastern Europe to Latin America, hundreds of millions of people throughout the world are caught in what President Clinton characterized in his 1999 State of the Union Address as "the most serious financial crisis in half a century. ${ }^{n 41}$ While some can weather the inevitable vicissitudes of free markets, ${ }^{42}$ the costs are often high, and may well be prohibitive for the already marginalized.

Even the U.S. Treasury has toned down its free market rhetoric, and it now warns of the dangers of unregulated capital flow. ${ }^{43}$ While the World Bank no longer imposes the kind of stringent Structural Adjustment Programs (SAPs) that dominated the $1980 \mathrm{~s},{ }^{44}$ lenders still want assurances that their loans will be

39. At a meeting of the G7, the Japanese Prime Minister called for a discussion of the financial instability in Thailand. He was "typically understated, tentative and vague (as is considered polite in Japan) and did not call for any specific action." While the Japanese officials waited expectantly, President Clinton and the other world leaders ignored the Prime Minister's request. See id. at $\mathrm{A} 1$.

40. Brazil was following the advice of the IMF with respect to austerity measures, for example. The collapse of the baht also affected economies that were doing nothing right, like Russia. For an account of the collapse of the Russian economy and its impact on Brazil, see THOMAS L. FRIEDMAN, THE LEXUS AND THE OLIVE TREE at xi (1999).

41. Kristof 8 Wyatt, supra note 24 , at A1. There are two main schools of thought as to the primary cause of the continuing crisis. First, Jeffery Sachs of Harvard University attributes it to panic. See, e.g., Jeffrey D. Sachs, Globalization and the Rule of Law, Yale Law School Occasional Papers, 2d Series, No. 4 (1998). Paul Krugman of the Massachusetts Institute of Technology attributes it more to structural weaknesses. See Kristof \& Sanger, supra note 26, at 8 . For a more optimistic view, see Michael M. Phillips, Apocalyse? No: Round the Globe, Signs Point to Final Days of the Financial Crisis, WALl ST. J., Apr. 14, 1999, at A1 (explaining that "the global financial crisis appears to have bottomed out" although "Russia bleeds billions").

42. See id.

43. See Kristof \& Sanger, supra note 26, at A1. As Muhammed Yunus has observed, "[U]nrestrained growth is the ideology of the cancer cell." Muhammad Yunus, Redefining Development, in 50 YEARS Is ENOUGH: THE CASE AGAiNST THE WORLD BANK AND THE INTERNATIONAL MONETARY FUND (Kevin Danaher ed., 1999).

44. See, e.g., WOMEN AND ADJUSTMENT POLICIES IN THE THIRD WORLD (Haleh Afshar \& Carolyne Dennis eds., 1992). According to Gracia Clark,

[f]or many in the developing world, the policy regime called "structural adjustment" provides the ideological and financial discipline for establishing global space in a country as a whole. Loan conditionalities force national governments to dismantle regulatory controls, restrict 
repaid. ${ }^{45}$ Belt-tightening remains very much a part of the agenda. 46

Under NAFTA, for example, the Mexican "economy grew at a rate of $4.8 \%$ last year, adding 100,000 new manufacturing jobs." ${ }^{\text {47 }}$ But "[j]ust since 1997, the number of people living in extreme poverty-defined as workers earning less than $\$ 2$ a dayhas grown by four million, or twice the growth of the population."48 Despite the

prevailing view from Wall Street and Washington ... of a country that got over a bad stretch a few years ago, and whose experience should serve as a lesson for other emerging markets in crisis ... [,] Mexico's lesson for other troubled economies is something very different: [s]ometimes macroeconomic health is achieved at the cost of mass hardship-and even then, timing may be just as important as policy. 49

subsidies to tax holidays for investors, and build appropriate transport and communications infrastructure.

Gracia Clark, Implications of Global Polarization for Feminist Work, 4 IND. J. GLOBAL LEGAL STUD. 43, 47 (1996). Under structural adjustment, protective and collective labor regulations have been eroded, along with employment security. See Guy Standing, Global Feminization Through Flexible Labor: A Theme Revisited, 27 WORLD DEV. 583, 584 (1999); cf. Nicholas D. Kristof, World Ills Are Obvious, The Cures Much Less So, N.Y. Times, Feb. 18, 1999, at A1. President Kim Dae Jung of South Korea argues that the crisis has been beneficial: "I believe that having to restructure our economy under the agreement of the IMF is ultimately a big help for our economy."). Id. See generally KATHY MCAFEE, STORM SIGNALS: STRUCTURAL ADJUSTMENT AND DEVELOPMENT ALTERNATIVES IN THE CARIBBEAN 69-79 (1991) (describing the origins of SAPs).

45. See id.

46. A recent bill sponsored by Congressman Charles Rangel of Harlem (N.Y.), for example, would require African nations to make stringent economic commitments in return for U.S. trade concessions. Illinois Representative Jesse Jackson, Jr. called the plan "'a crime against humanity' that takes food from the mouths of African babies." He proposed an alternative measure which would provide aid, such as debt relief. But African trade and finance ministers, in Washington for a State Department meeting, supported the Rangel plan. "We know the Jessie Jackson [Jr.]'s bill doesn't have a chance of passing," said one. "We're not stupid." Ronald G. Shafer, Washington Wire, Wall ST. J., Mar. 19, 1999 , at A1.

47. Joel Millman, Is the Mexican Model Worth the Pain?, WALl ST. J., Mar. 8, 1999 , at A1.

48. Id. For a detailed description of the Mexican crash, see GRAY, supra note 10 , at 22 . But $c f$. Kristof, supra note 44 , at A1 (noting that the "worst-off in the worst-off country [Indonesia] are still better off than they were ten years ago. Now, they have electricity, paved roads, and toilets.").

49. Kristof \& Sanger, supra note 26, at A10. As Sassen notes, the Mexican crisis "was handled not by the secretary of state-as it would have been twenty years ago-but by the secretary of the treasury, Robert Rubin ... [the former] socalled dean of Wall Street." SASSEN, supra note 2, at 23. For an in-depth analysis of the Mexican crisis and its implications for global banking and finance, see 
2. Culture

It is not just dollars that are flowing freely around the world, but Western culture ${ }^{50}$-constitutionalism and Coca Cola, free market ideology and Bruce Willis. ${ }^{51}$ Every state has had a taste of relentless, technology-enhanced consumerism, free market democracy promoted by advertising so creative, so well done, that no culture is impenetrable. ${ }^{52}$ It seeps in everywhere. In even the poorest states, wealthy elite import Western luxuries. ${ }^{53}$ States that try to close themselves off are quickly condemned for denying free speech and free expression, those basic civil rights and freedoms backed by the United States, the United Nations, and the full weight of the market. 54

As Fredric Jameson explained over fifteen years ago, mass production of goods has been superseded by the mass production of image, ${ }^{55}$ from American soap operas to McDonald's,

Timothy A. Canova, Banking and Financial Reform at the Crossroads of the Neoliberal Contagion, 14 AM. U. INT'L L. REV. 1571 (1999).

50. As Professor Falk observes, "Western [has been] further deconstructed to be seen as American." FaLK, supra note 14, at 49 .

51. "The most widely recognized instance of Americanization is seen, of course, in the profound influence U.S. popular culture exerts on global culture." SASSEN, supra note 2, at 19 :

52. "Especially with the help of the new technological media of reproduction and dissemination monopoly capitalism has succeeded in swallowing up all forms of older popular cultures, in homogenizing all and any local or regional discourses, and in stifling by co-option any emerging resistances to the rule of the commodity." HUYSSEN, supra note 19, at 21 .

53. See Mobutu's Xanadu, N.Y. TIMES, Sept. 26, 1999, 86 (Magazine), at 82 (describing Gbadolite, a remote village in the Congo, that dictator Mobutu filled with three palaces, a high-rise luxury hotel, and a conference center).

54. These are promoted politically, through free market democracy, and legally, through instruments such as the ICCPR and the U.S. Constitution, as well as more informally through advertising and shifting cultural norms that increasingly value acquisition. Huyssen cites Adorno, Horkheimer, Enzensberger, and, in the United States, Herbert Schiller, for the proposition that "modern mass culture is administered and imposed from above and that the threat it represents resides not in the masses but in those who run the industry." HUYSSEN, supra note 19 , at 48 .

55. Cf. Fredric Jameson, Postmodernism, or the Cultural Logic of Late Capitalism, NEw LEFT REV., July-Aug. 1984, at 53, 59. No one would invest in "Third World markets," for example, so the International Finance Corporation of the World Bank repackaged them as "emerging markets," with what turned out to be irresistible connotations of getting in on the ground floor. See Kristof \& Sanger, supra note 26, at A1. But image plays both ways. In Europe, for example, after several dozen Belgian school children became nauseous after drinking Coke, rumors quickly spread and turned into a public relations nightmare. "[T]he company's inability to contain the growing alarm shows how quickly a global icon can be knocked off center." James R. Hagerty \& Nikhil Deogun, Coke Scrambles to Contain a Scare In Europe, WAll ST. J., June 17, 1999, at $B 1$. 
proliferating in endless iterations around the world. ${ }^{56}$ Cultures are open as never before to question, challenge, and influence from outside. No walls can keep out satellites and cyberspace. ${ }^{57}$

Western culture is ubiquitous, but it is not always welcome. ${ }^{58}$ There is a growing backlash-or rather, a growing number of distinct, independent backlashes-against Western culture, ${ }^{59}$ not only from Muslim fundamentalists but also from those who question the U.S. model of laissez faire capitalism, which "rescues Connecticut hedge funds but sacrifices Indonesian children. ${ }^{n 60}$

The impact of globalization on culture is complex and the impact on women is especially so. ${ }^{61}$ How does globalization undermine local culture? ${ }^{62}$ How does local culture subordinate women?63 How does local culture meet women's needs?64 This section first draws on Thomas Friedman's recent account of

56. See generally HUYSSEN, supra note 19 , at ix.

57. Many have tried. See, e.g., FRIEDMAN, supra note 40 , at 55 (describing China Online, a news service for average Chinese citizens, that Beijing cannot stop).

58. Dau-Schmidt, supra note 7, at 57 (explaining that insofar as American culture subverts local cultural norms such as female subordination, globalization will "provide women with greater opportunities ... . . To the extent that globalization breaks down cultural norms that are protective of vulnerable women and meet women's needs, women will of course suffer.").

59. See, e.g., French Farmers Protest, Knoxville News-SEntinel, Sept. 5, 1999 (photograph of the McDonald's restaurant in Salon de Provence, overrun with turkeys, chickens, and geese brought in by angry French farmers to "protest ... American trade muscle, globalization and its effects on agriculture.").

60. Kristof \& Wyatt, supra note 24, at A1. See also Kristof, supra note 44, at A1 (describing the collapse of the Multilateral Agreement on Investments (MAI), following its rejection by France, Australia and Canada); Noam Chomsky, Hordes of Vigilantes and Popular Elements Defeat MAI, For Now, Z MAG., July-Aug. 1998, at 51 (describing how popular elements defeated the MAI).

61. Both idealized and relativized accounts of justice look inadequate from the perspective of those whom they marginalize. Women, in particular poor women, will find that neither approach takes account of the reality of performing both reproductive and productive tasks, while having relatively little control over the circumstances of one's life.

Onora ONeill, Justice, Gender and International Boundaries, in THE QUALITY OF LIFE, supra note 34 , at $303,303$.

62. See generally Lea Brilmayer, Trade Policy: The Normative Dimension, 25 N.Y.U. J. INT'L L. \& POL. 211, 216-17 (1993). But see RYAN BISHOP \& LILLIAN S. ROBINSON, Night MARKET: SEXUAL CULTURES AND tHE ThaI ECONOMIC MIRACle 11 (1998) (rural Thai families now celebrate the birth of a daughter, who can be sold into prostitution, showing how "capitalist markets ... reinforce traditional structures of privilege.")

63. See, e.g., MARTHA C. Nussbaum, SEX AND Social Justice 29-54 (1999) (discussing women and cultural universals).

64. As Oscar Schachter notes, "Localism . . . [may] be used to deprive vulnerable groups of benefits and protection that they receive from the central state." Oscar Schachter, The Decline of the Nation-State and its Implications for International Law, 36 CoLUM. J. TRANSNAT'L L. 7, 17 (1997). 
globalization, The Lexus and the Olive Tree. ${ }^{65}$ Because Friedman's model neglects women, however, I also draw on Arundhati Roy's more nuanced metaphor of the "Intercontinental Hotel" to show how that experience can be included.

\section{a. The Lexus and the Olive Tree}

Friedman explains globalization by juxtaposing the Lexus-a new, fast, Western, expensive car and the emblem of a consumer culture driven by cheap gas-and the olive tree, symbol of ancient loyalties, rootedness, tradition, and sustenance. His thesis is that globalization is inevitable because everyone wants a Lexus, or at least the more mundane comforts of Western affluence, such as electricity, running water, toilets, and refrigerators. ${ }^{66}$ According to Friedman, the United States is the primary beneficiary of these new markets and should accordingly assume the responsibilities that accompany privilege. ${ }^{67}$ Some olive trees will have to be cut down to make roads, he recognizes, but perhaps some can be spared. ${ }^{68}$ Some people, he notes, will not be able to "keep up" with the pace set by a high-tech, knowledge-based consumer society. ${ }^{69}$ These "turtles,"70 as he patronizingly calls them, must be assured a safety net. ${ }^{71}$ The Lexus and the olive tree is a reductionist but compelling metaphor for neoliberalism.

The Lexus and the olive tree metaphor is particularly apt here because so many developing countries lack roads. Even where there are roads, women are often prohibited from driving on them, either through law or custom. ${ }^{72}$ Even where there are no such prohibitions, few women in the world can afford gas. Only a token number, most of whom are in the United States, could

65. FRIEDMAN, supra note 40. Friedman is the foreign affairs columnist for The New York Times.

66. See id. at 285-94 (describing "The Groundswell").

67. See id. at 352 .

68. See id. at 376.

69. Id. at 273 .

70. Id.

71. See id. at 354 .

72. See Martha Chen, A Matter of Survival: Women's Right to Employment in India and Bangladesh, in WOMEN, CULTURE, AND DEVELOPMENT: A STUDY OF Human CAPABILITIES 37, 38 (Martha C. Nussbaum \& Jonathan Glover eds., 1995) [hereinafter WOMEN, CULTURE] (noting that "the public sphere of markets, roads and towns is predominantly male"). 
afford-or would want-a Lexus. ${ }^{73}$ The Lexus is coded Western "male," while the olive tree is coded Third World "female."74

b. The Intercontinental Hotel

S. Patrick: You are still wrecked among heathen dreams.

$$
\text { -W. B. Yeats, The Wanderings of Oisin } 75
$$

The Intercontinental Hotel offers a more inclusive metaphor for the impact of globalization on culture in general and, more specifically, on the women in those cultures. Saskia Sassen describes the emergence of a new international society, comprised of those who direct the money flows described above, ${ }^{76}$ and women's role in that society. Although many of its activities are virtual, this society has an actual physical presence throughout the world, particularly in the cities that serve as financial capitals. If capital flows to a new region, representatives from this international society must follow to inspect the site and to meet the local players. This can produce additional investment in the region through tourism, including sex tourism.

As Sassen explains, these travelers require a veritable army of international support workers to make them comfortable. This army is directed and organized by multinational hotel chains, which feminist economist Gracia Clark refers to collectively as the Intercontinental Hotel. ${ }^{77}$ Its advertisements are in every weekly U.S. magazine. They promise the traveler all the Western amenities along with an authentic experience of the region between meetings. ${ }^{78}$ Women, usually from the developing world, serve a vital role:

By carefully replicating the culture and infrastructure of the Intercontinental Hotel worldwide, these support workers make it

73. Europeans also generally want smaller cars, not only because it can cost $\$ 75$ to fill a tank, but also because of the difficulties in parking and maneuvering in older cities and villages.

74. Women are usually responsible for maintaining traditional cultures, even, or especially, those aspects that most oppress them. See generally NuSsBaUM, supra note 63. Similarly, in A Prayer for my Daughter, Yeats compares his daughter to a laurel tree. See infra note 400 and accompanying text; see also infra note 404 (criticism).

75. VARIORUM EDITION, supra note 1, at 4.

76. See supra Part II.A.1.

77. Clark, supra note 44 , at 44.

78. See, e.g., NEW YORKER, Nov. 15, 1999, at 3 (advertisement for Hyatt stating, "You may not master the ukulele in one lesson, but you'll no doubt feel a connection with the culture that made it legendary."). Friedman cites Madison Avenue throughout his book, noting without irony that "[f]or some reason, advertising copywriters have a tremendous insight into globalization." FRIEDMAN, supra note 40 , at 381 . 
possible for the globe-trotting executive to believe himself a culturally neutral technocrat. Would-be elite candidates cannot, in fact, decontextualize themselves, but must rely on the skill and invisibility of these unacknowledged others to accomplish it for them. Cleaners, personal secretaries, security guards, repairers, and deliverers meticulously remove and absorb all traces of the actual physical and cultural location, which can mean solving quite different concrete problems depending on local circumstances. ${ }^{79}$

Arundhati Roy provides an unforgettable example in her Booker Prize-winning novel, The God of Small Things. ${ }^{80}$ She describes the purchase of the History House in Kerala, India by an international hotel chain. The History House was built by a British colonial officer who had "gone native" and, rumor had it, freely indulged his pedophilic appetites. The structure was called the History House by locals because of all that had happened there, from the molestation of local boys to the vicious murder of a communist "untouchable" by the local police. Local culture, Roy shows us, is a complex and subjective construction, rich and ancient, overlaid with the postcolonial struggles of those still subject to a brutal caste system, with various factions grasping for control of the Indian government and seeking to control the local economy.

In the 1990s, however, all of this troublesome history is cauterized, replaced by a picturesque, sanitized version of the Intercontinental Hotel. Does the loss of history matter? Roy shows how robbing a people of their history-especially a history of pain and oppression-deprives them of any possibility of coming to terms with it. ${ }^{81}$ As Jose Alvarez has pointed out, however, much of the law that facilitates globalization makes the question impossible. ${ }^{82}$ In the NAFTA agreement, for example, the chapter on investment does not distinguish between the sale of a cultural icon and that of any other commodity. ${ }^{83}$

79. Clark, supra note 44 , at 44 .

80. ARUNDhaTI ROY, THE GOD OF SMALl ThINGS (1998).

81. Near the end of the novel, there is a surreal all-night performance in the History House by a drama troupe (or its sorry, strung-out remains) still performing the ancient Indian plays. See id.

82. See José E. Alvarez, Critical Theory and the North American Free Trade Agreement's Chapter Eleven, 28 U. MIAMI INTER-AM. L. REV. 303, 306 (1997).

83. See id. See also id. at 308:

Except for relatively weak side agreements, which deal with environmental and labor issues, [NAFTA] . . . is effectively silent with respect to the rights of others, who may be affected by FDI flows, and .... ignores many of the other rights also contained in the Universal Declaration of Human Rights. In the chapter protecting the rights of businesses, there is no mention of a human being's right to "economic" rights "indispensable for . . . dignity and the free development of ... personality." 


\section{B. Women in the Global Economy}

While women are obviously a diverse group, compared to men they are overwhelmingly disadvantaged economically. ${ }^{84}$ This is shown starkly and redundantly in U.N. data. ${ }^{85}$ The question here, however, is whether globalization improves women's situation or makes them worse. The answer, of course, depends on which women we are talking about ${ }^{86}$ and what is being measured.

This section addresses the question from two perspectives. First, it draws on the recent work of economists to provide a statistical overview and a closer look at trends and counter-trends regarding women's participation in the global economy. Even the most robust economic model, however, cannot convey the subjective experience of economically marginalized women. The second part of this section concludes, accordingly, with a series of brief narratives or "snapshots."

\section{Data}

a. An Overview: Statistics

Those Platonists are a curse,' he said, 'God's fire upon the wane, A diagram hung there instead, More women born than men.'

As Noeleen Heyzer, Director of UNIFEM, observed at the Beijing Conference on Women in 1995:

It is not acceptable for women to constitute 70 percent of the world's 1.3 billion absolute poor. Nor is it acceptable for women to work two-thirds of the world's working hours, but earn only onetenth of the world's income and own less than one-tenth of the world's property. 88

84. See WOMEN, CULTURE, supra note 72 , at 16-34 (tables showing that no country treats women as well as it treats its men).

85. See, e.g., About UNIFEM (visited Apr. 2, 2000) <http://www.unifem. undp.org/about.htm> (quoting Noeleen Heyzer, Director of UNIFEM).

86. See supra notes 2, 4-8 and accompanying text.

87. VARIORUM EDITION, supra note 1, at 485.

88. About UNIFEM, supra note 85. See also Dau-Schmidt, supra note 7, at 53-54, which notes that

the basic pattern of more work and less remuneration seems stable across the planet. Although harder to quantify, it seems fair to assert that women often contribute more to social relationships with men and enjoy less of the surplus from these relationships. Worldwide, women do the majority of work in maintaining the household and rearing children . . . . 
As Harvard economist Amartya $\operatorname{Sen}^{89}$ has demonstrated, the data both overstates and understates women's economic subordination. ${ }^{90}$ First, such statistics understate women's economic subordination because they omit the women presumably born who never appear in the statistics. Sen summarizes the research showing a substantial biological component favoring women.91 If women are treated as well as men-that is, if they receive a proportionate amount of food, health care, and other resources-there should be more women than men. Using the sub-Saharan African ratio (1.02) of females to males,92 Sen estimates the number of "missing women" at "more than 100 million."93 These are the abandoned infant girls in China, the brides who die in kitchen fires in India, the baby girls in Africa who are not taken to the clinic to be treated for diarrhea as quickly as their brothers-the women and would-be women who have been unable to claim enough of the world's resources to survive. ${ }^{94}$

The basic reasons why women fare so poorly in the division of the cooperative surplus with men are that, in all possible means of exchange, women suffer disadvantages due to their physical differences from men as well as cultural and religious beliefs about the appropriate roles of women.

See also Tzannatos, supra note 4, at 551 (noting that "[m]ost of the work performed by females is not paid").

89. See Amartya Sen, Capability and Well-Being, in THE QUALITY OF LIFE, supra note 34, at 30. Sen won the Nobel Prize for economics in 1998 for his work on poverty, famine and human rights. He used $\$ 400,000$ of the $\$ 940,000$ prize to set up charitable foundations in India and Bangladesh. See Sylvia Nasar, Nobel Economics: Spending the Check, N.Y. TIMES, Dec. 5, 1999, sec. 3 at 1 .

90. See supra note 34 and accompanying text.

91. See AMARTYA SEN, INEQUALITY REEXAMINED 123-24 (1992). As Yeats notes, there are "[m]ore women born than men." VARIORUM EDITION, supra note 1 , at 485 .

92. In Europe, the ratio is 1.05; in North America, 1.047. See Martha C. Nussbaum, Introduction to WOMEN, CULTURE, supra note 72, at 1, 3 (citing Drèze \& Sen). But sub-Saharan Africa is considered a more conservative standard for the developing world.

93. Amartya Sen, More Than 100 Million Women Are Missing, N.Y. REv. Books, Dec. 20, 1990, at 61, cited in HENRY J. STEINER \& PHILIP ALsTON, INTERNATIONAL HUMAN RIGHTS IN CONTEXT: LAW, POLITICS, MORALS 896 (1996). In India, 36.7 million are missing, in China 44 million, in North Africa 2.4 million, and in Latin America 4.4 million. See WOMEN, CULTURE, supra note 72 , at 3.

94. This would include the rural Chinese women for whom suicide has reached epidemic proportions. The rate is five times that of other countries. See Elizabeth Rosenthal, Women's Suicides Reveal Rural China's Bitter Roots, N.Y. TIMES, Jan. 24, 1999, sec.1, at 1. See also Hilary Charlesworth, Feminist Methods in International Law, 93 AM. J. INT'L L. 379, 388 (1999) ("When food is scarce, more women than men suffer from malnutrition, often because of cultural norms that require men and boys to eat before women and girls."); Richard Rorty, Human Rights, Rationality, and Sentimentality, in ON HUMAN RIGHTS: THE OXFORD AMNESTY LECTURES 111, 124 (1993) (Stephen Shute \& Susan Hurley eds., 1993.) ("For most 
Second, the picture shifts depending on whether, like Heyzer, we focus on commodities and income or whether we focus on what Sen calls "functionings and capabilities."95 In China, Sri Lanka, and Costa Rica, for example, communal health services, medical care and basic education produce a quality of life superior to that which would be expected by the income indicators. 96 The example of the Indian state of Kerala is illuminating: While incomes within this Indian state are among the lowest, residents have the highest life expectancy at birth, a comparatively very low infant mortality rate, and higher level of literacy (especially female literacy, eighty-seven percent compared to the national average of thirty-nine percent). ${ }^{97}$

b. A Closer Look: The Feminization of Labor

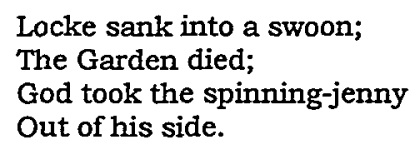

-W. B. Yeats, Fragments 98

Recent research shows that while a small group of women have earnings on a par with men, the overwhelming majority of the world's women continue to earn significantly less than men. This is largely attributable to (1) the kind of work women do, and (2) their uncompensated "women's work," including their reproductive work. ${ }^{99}$ In addition, researchers deplore the relative lack of gender-aggregated data and the resultant economic invisibility of the world's women, especially the most marginalized. 100

males in countries in which the average annual income is under $[\$ 4,000]$, most females still do not... count.").

95. See SEN, supra note 91 , at 39.

96. See id. at 126.

97. See id. at 126-27. Kerala is the site of The God of Small Things, supra note 80 .

98. VARIORUM EDITION, supra note 1, at 439. The spinning-jenny, an early industrial machine, is thus linked to liberal philosopher John Locke. See GloRIA C. KLINE, THE LAST COURTLY LOVER: YEATS AND THE IDEA OF WOMAN 10 (1983) (quoting Yeats, "There is an astrological sense in which a man's wife or sweetheart is always an Eve made from a rib of his body . . . . She is [the] external expression [of] an element in his character and his destiny."). See HUYSSEN, supra note 19 , at 44-62.

99. Tzannatos, supra note 4 , at 551 .

100. See generally MARILYN WARING, IF WOMEN COUNTED: A NEW FEMINIST ECONOMICS (1988). 


\section{i. Wage Differentials}

Women earn less than men everywhere. ${ }^{101}$ They are paid less than men for doing the same work, and they are limited to low-income sectors by widespread sex-based occupational segregation. 102 In Brazil, for example, income earned by women is equivalent to fifty-four percent of that received by men. 103

Globalization, however, seems to be narrowing the gap. Drawing on the first British survey of wages in 1886, and data available from the first half of the twentieth century as well as post-war annual surveys, economist Zafiris Tzannatos shows that women's pay remained

remarkably stable at around two-thirds of male pay until 1970.

Then, female earnings increased to three-quarters of men's earnings in a period of less than 10 years .... Compared to [the] century-long scenario for industrialized countries, the evidence ... suggests that in many developing countries significant changes have taken place within the last few decades. ${ }^{104}$

In Costa Rica, for example, the average monthly salary of women was eighty-two percent of that of men in 1990.105 In Uruguay women earned seventy-five percent of the income received by men. 106

\section{ii. Women's Work}

Globalization has transformed labor: "The concept of regular, full time wage labor . . . has been giving way to a more diverse pattern, characterized by 'informalization' of employment, through more outworking, contract labor, casual labor, part-time labor, homework and other forms of labor beyond the protection of labor

101. According to the United Nations, women's wages are less than those of men in 37 countries for which data are available. See Mehra \& Gammage, supra note 4 , at 545 . This is lessening in some places, but it is increasing in others. See id. at 546. But cf. id. at 543 (although women are underrepresented in administrative and managerial positions, their representation has been growing since 1980 everywhere except south Asia).

102. "Nearly half of all working women in developed countries are in clerical, sales or service jobs and just a fourth in professional and managerial jobs." Id. Standing cites "a recent exhaustive assessment [showing] some decline in the extent of sex-based occupational segregation in most parts of the world." Standing, supra note 44 , at 600 . He notes, however, that "[t]his too may largely reflect the weakening position of men rather than any dramatic improvement in the occupational opportunities of women." Id.

103. See OAS, REPORT OF THE INTER-AMERICAN COMMISSION ON THE STATUS OF WOMEN IN THE AMERICAS 28-29 (1998).

104. Tzannatos, supra note 4, at 552. See also Eisenstein, supra note 10 , at 67-68 (noting that [women] become the "third world of the third world," the "third world of the first world," and "the cheapest of the cheap workers").

105. See Tzannatos, supra note 4 , at 552 .

106. See OAS, supra note 103 , at $28-29$. 
laws."107 Sixty-one percent of the world's workers are employed in the "informal sector." 108 This term includes "farming, cottage industries, tool-making and garment-making, and in urban areas, petty trading . . . [fruit and vegetable selling] and small-scale manufacturing enterprises."109 As economist Martha Chen notes, " $80 \%$ of workers in low-income countries and more than $40 \%$ of workers in middle-income countries operate in informal and rural labor markets, beyond the reach of trade unions and direct government intervention."110 In every country, more women than men are employed in such markets. ${ }^{111}$

The informal sector is crucial to the economic survival of poor women, ${ }^{112}$ as well as the economies of developing states. In dynamic, export-oriented subsectors, informal workers subsidize capitalist growth "by providing infrastructure, tools, equipment and often working below minimum wages in highly insecure and contingent employment."113 In addition, as Sassen observes, women subsidize the "waged labor of men through their household production and subsistence farming."114

107. Standing, supra note 44, at 587. For a historical overview of "Women in Development," see ROSI BRAIDOTTI ET AL., WOMEN, THE ENVIRONMENT AND Sustainable DevelopMENT: TOWARDS A THEORETICAL SyNTHESIS 78-83 (explaining that the Women in Development movement altered society's view of women in economics and politics).

108. Martha Chen et al., Counting the Invisible Workforce: The Case of Homebased Workers, 27 WoRLD DEV. 603, 603 (1999). Martha Chen describes three views of the "informal sector." Id. at 604. First, she identifies the selective reality view-i.e., that "as GDP per worker rises, the share of the workforce in the ... formal sector rises." Id. Second, she describes the global reality view, which simply notes that "the share of the work force in [the] ... formal sector slowed down or absolutely declined in the 1980s and 1990s." Id. Finally, she presents the third view, gender reality, which argues that "much of women's paid worknot just their unpaid housework-is not counted in official statistics. [If it were, it] ... would challenge our empirical understanding not only of the informal sector but also of the economy as a whole." Id.

109. Mehra \& Gammage, supra note 4, at 542. See also Chen et. al. supra note 108, at 603 . This includes "street vendors in Bogota, shoeshine workers in Calcutta, garbage collectors in Cairo, textile waste recyclers in Manila, homebased garment workers in Buenos Aires, and homebased electronics workers in West Yorkshire." Id. at 603. Chen summarizes the four theories for the persistence of informal sector activities in developing countries: (1) the "lack of growth" theory; (2) the "jobless growth" theory; (3) the "growth from below" theory; and (4) the "period of adjustment" theory. Id. at 604.

110. Chen et al., supra note 108, at 603 (citing 1995 World Bank data). See generally Saskia Sassen, The Informal Economy: Between New Developments and Old Regulations, 103 YALE L. J. 2289 (1994).

111. See Mehra \& Gammage, supra note 4 , at 541 .

112. See id.

113. Id. at 535.

114. Sassen, supra note 4 , at 11 . 
Homework is an important part of the informal sector because it enables women to participate in the market economy, however marginally, and still do their unpaid work, including reproductive work, in the home. Homeworkers comprise a large and growing segment of the labor force in many countries. ${ }^{115}$ Wherever sex-aggregated data is available, it shows that more women than men are employed in homework. In Greece, Ireland, Italy, and the Netherlands, for example, up to $95 \%$ of homeworkers are women. 116

Women are also playing a larger role in agriculture. ${ }^{117}$ Because of expanding opportunities for men outside agriculture, land degradation, drought, and other factors that reduce farm yields, men have abandoned their farms, leaving the women in charge in Honduras, Nepal, southern and eastern Africa, and Yemen. ${ }^{118}$ Women farmers, however, generally have less access to resources such as credit and farm implements. ${ }^{119}$ They also have historically been neglected by agricultural extension services. ${ }^{120}$

Some economists theorize "that it is the spread of more flexible and informal employment that accounts for most of the upward trend in the female share of the labor force," noting that women predominate "[in] industries where profit margins are protected by reducing labor costs, extending hours and decreasing the numbers of formal production workers . . . .121 As economist Guy Standing notes, flexibility means opportunity, but it also means insecurity. ${ }^{122}$

Women with dependent children may be desperate for opportunity, but they are also especially vulnerable; rapidly changing markets put not only their businesses, but also their children at risk. Thus, some feminist economists urge that "reproduction and unpaid work be recognized [as] economic

115. See Mehra \& Gammage, supra note 4, at 541. For statistical evidence showing that homebased work is an important source of work throughout the world, especially for women, and that homebased workers comprise a significant share of the workforce in key industries, see Chen et al., supra note 108, at 60507.

116. See Mehra \& Gammage, supra note 4, at 541.

117. See id. at 534. Women, like men, are moving out of the agricultural sector, but they are doing so at a slower rate. See id. For an account of women's traditional role in agriculture in the developing world, see generally ESTER BOSERUP, WOMAN'S ROLE IN ECONOMIC DEVELOPMENT (1986).

118. See Mehra \& Gammage, supra note 4, at 539.

119. See id. (noting extensive literature developed over the past 20 years documenting difficulties faced by women farmers).

120. See id.

121. Id. at 534.

122. See Standing, supra note 44 , at 584-86. 
activities."123 Because women frequently work in the home, benefits and other social assistance/insurance should be the concern of broad public policies and not just... Iinked to employers or enterprises. ${ }^{124}$

iii. Lack of Data

Data assessing the impact of globalization on women remains largely unavailable. ${ }^{125}$ In Southeast Asia, for example, the Women Leaders Network (WLN), ${ }^{126}$ recently deplored the absence of the "sex-disaggregated data and analyses . . . essential to effective policy-making, and the success of APEC programs and projects."127 Arguing that women have borne the brunt of financial and economic turmoil in the region, the group insists "that the full impact of the crisis on women and women's livelihoods has to be fully understood and addressed."128

The lack of data on women reflects the widespread invisibility of women's work, as well as state apathy. Women's efforts to compensate for declining household incomes during recession, for example, are "not always picked up in official data" because such efforts are often concentrated "in the unrecorded informal sector."129

123. Tzannatos, supra note 4 , at 567 .

124. As Diane EIson explains, "most labor market institutions are constructed on the basis that the burdens of the reproductive economy will be borne largely by women." Mehra \& Gammage, supra note 4, at 535 . Even emerging labor trends, such as homework and informal work, that allow women to participate both in the market and in older models of labor that had previously not contemplated women's participation, continue to assume that the burdens of the reproductive economy will be placed on women.

125. See BRAIDOTTI ET AL., supra note 107, at 139-40 (discussing U.N. System of National Accounting's Liabilities).

126. The WLN was founded in 1996 to promote the integration of gender perspectives into APEC (Asia Pacific Economic Cooperation). See Recommendations: Declaration of the Women Leader's Network (1998) (visited Apr. 6, 2000) <www.unifem.undp.org/trade/rec7.htm> (Declaration and Recommendations of the WLN at its Third Meeting, Kuala Lumpur, Malaysia, Sept. 1-2, 1998).

127. Id.

128. Id. In WLN's workshop addressing the economic crisis and its impact on women, its first recommendation was to "[e]stablish and expand social safety nets for women, by taking actions such as . . . [p]romoting access to credit and alternative methods of financing women's [businesses including micro-enterprises, and promoting] women's knowledge and awareness of the economic crisis and the effects of trade liberalization and globalization on women ...." Id. See also Mehra \& Gammage, supra note 4, at 547 (urging improvements in data collection through national censuses and employment surveys).

129. Mehra \& Gammage, supra note 4, at 537. As Standing notes, national statistics on "wage differentials in developing countries is again deplorably patchy." Standing, supra note 44 , at 590. 


\section{Snapshots ${ }^{130}$}

Subjective experience cannot be captured in statistics. The next section consists of four brief narratives, or snapshots, that show a few of the ways in which globalization affects not only markets but individual women. While the following snapshots do not purport to be representative, the problems each of these women face affect many others as well. ${ }^{131}$ The importance of such snapshots, moreover, is increasingly recognized. ${ }^{132}$ They suggest a range of experience otherwise omitted, and the experience of the marginalized is particularly at risk of being lost.

\section{a. A Teenager in the Maquiladoras}

Ofelia earns about thirty dollars for a forty-four-hour week (eight hours a day for five days a week, four hours on Saturdays) working in a maquiladoras factory on the U.S.-Mexican border. ${ }^{133}$ She lives in Anapra, a colonia (neighborhood) in a raw settlement emerging on top of a landfill right across the border from E1 Paso, Texas. ${ }^{134}$ The houses in Anapra are made of cardboard,

130. Cf. STEINER \& ALSTON, supra note 93, at 3-25 (introducing human rights text with brief "human rights stories").

131. See, e.g., Nicole L. Grimm, Comment, The North American Agreement on Labor Cooperation and its Effects on Women Working in Mexican Maquiladoras, 48 AM. U. L. REv. 179 (1998) (discussing women in the Maquiladoras); Frances Elisabeth Olsen, Feminism in Central and Eastern Europe: Risks and Possibilities of American Engagement, 106 YALE L. J. 2215, 2217 (1997); GENDER POLITICS AND POST-COMMUNISM: REFLECTIONS FROM EASTERN EUROPE AND THE FORMER SOVIET UNION (Nanette Funk \& Magda Mueller eds., 1993) (discussing women in the former Soviet Union); LINDA GORDON, PITIED BUT NOT ENTITLED: SINGLE MOTHERS AND THE HISTORY OF WELFARE 1890-1935 (1994); THEDA SKOCPOL, PROTECTING SOLDIERS AND Mothers: THE POLITICAL ORIGINS OF SOCIAL POLICY IN THE UNITED STATES (1992) (discussing single mothers in the United States); Margarita M. Valdes, Inequality in Capabilities Between Men and Women in Mexico, in WOMEN, CULTURE, supra note 72, at 426; authorities cited infra notes 157-163 (discussing Thai girls).

132. See Anne-Marie Slaughter \& Steven R. Ratner, The Method is the Message, 93 AM. J. INT'L L. 410, 422 (1999) (“'H]ow we talk about law can blind and deafen us to the demands of justice. Translation of social, economic and political needs into legal claims is a transformation of lived and felt experience into the dry distance of words and concepts .... ).

133. See Frances Lee Ansley, Rethinking Law in Globalizing Labor Markets, 1 U. PA. J. LAB. \& EMPLOYMEnT L. 369, 385 (1998). See also Mehra \& Gammage, supra note 4 , at 540 ("[W]omen [within the manufacturing sector] are concentrated in assembly line and production work that is semi-skilled, low wage, contingent and short term in that the labor force tends to be young unmarried women who are replaced when they marry or within a few years by young cohorts."). As export production becomes more technology dependent, the proportion of female workers fall. In the maquiladoras, for example, the proportion of female workers fell from $77 \%$ in 1982 to just under $60 \%$ in 1990 . See id. at 541.

134. See Ansley, supra note 133 , at $381-82$. 
discarded industrial pallets, automobile body parts, adobe, and cast-off asbestos board. ${ }^{135}$ There is no running water. ${ }^{136}$ Rather, the people in Anapra depend on a truck to bring them water. ${ }^{137}$ They store the water in "an elaborate collection of containers that allow for holding, using, and reusing water in various sequences .... Used chemical drums (with plenty of English-language warning labels) make handy water barrels."138 She began working in the factory when she was sixteen. ${ }^{139}$

\section{b. A Woman and Her Children in the Moscow Subway}

The photograph shows a heavy-set woman, probably in her early thirties, leaning against the wall in a Moscow subway, passively begging. ${ }^{140} \mathrm{Her}$ two children are at her feet-a six- or seven-year old is lying down, her head on the cement floor, and a slightly older girl is sitting up. ${ }^{141}$ No one is paying much attention to the photographer. ${ }^{142}$

This family is clearly among the two-thirds of the Russian population in need of some form of social assistance. ${ }^{143}$ The odds are good that the woman has been abused by her spouse ${ }^{144}$ and

135. See id. at 382.

136. See id. at 383.

137. See id.

138. Id.

139. See id. at 384. In Mexico, infant deaths due to malnutrition tripled in the last decade. See Millman, supra note 47, at A1. But see Jonathan Friedland, Mexico Tries to Take Politics Out of Welfare and Focus on Neediest, WALL ST. J., Oct. 15,1999 , at 1 (describing the annual $\$ 800$ million assistance program focusing on mothers in rural areas).

140. Global capitalism [has] dominate[d] [E]astern and [C]entral [E]urope since the revolutions of 1989 . The disintegration of the communist world [has] allow[ed] for a mobility of capital which ignor[ed] Cold-War boundaries. These corporations can now operate not merely without borders, but without responsibility'. As a result, [E]astern [E]urope has been repositioned globally as a new third world.

Eisenstein, supra note 10 , at 65 . As one commentator has noted, "Russia is not an 'underdeveloped' or 'developing' country. It's a misdeveloped country." Serge Schmemann, Russia Lurches Into Change, but the Old Ways, as Always, Prove Tenacious, N.Y. TIMES, Feb. 20, 1994, at A14.

141. See id.

142. See id.

143. See Summary Record of the 13th Meeting: Russian Federation, 13/05/97, Committee on Economic, Social and Cultural Rights, Doc. No. 13/05/97.E/C.12/1997/SR13 (1997). See also Standing, supra note 44, at 584 (describing "an erosion in the legitimacy of the welfare systems of industrialized countries").

144. See Summary Record of the 13th Meeting, supra note 143. Approximately 54,000 cases of spousal abuse were reported in Russia in 1997. See $i d$. These are covered by criminal laws against assault, according to the Russian representative. 
that she has had at least one abortion, because abortions outnumber live births in Russia two to one. 145 While her children (at least the two with her) are not yet among the growing number of street children in Russia, ${ }^{146}$ they have probably felt the impact of the "degradation of the educational system."147 The Russian stock market plunged eighty-four percent last year. ${ }^{148}$

\section{c. A Woman Leaving Her Children in Central Park}

In 1997, Lori-Ann Williamston left her three-year old and eight-month old daughters in a stroller in a playground in Central Park in New York City. ${ }^{149}$ The stroller was packed with cereal, baby formula, clothing, and toys. ${ }^{150}$ She told her children that she was going to get them ice cream and left. ${ }^{151}$ After forty-five minutes, a nanny taking care of another child in the playground called the police. ${ }^{152}$

The children were placed with Children's Services. ${ }^{153}$ Williamston was arrested at the apartment where she paid $\$ 100$ per month for a portion of the living room, where she lived with the two girls. ${ }^{154}$ The tenant and her teenage son occupied the apartment's two bedrooms. ${ }^{155}$ When Williamston was arrested, she explained that she had been depressed. ${ }^{156}$ Unable to find work that allowed her to take care of her children, she said she "knew that if [she] left the children in the park, the police would take care of them. ${ }^{n 157}$

145. See id.

146. A modest increase in the number of street children was reported in 1997. See id.

147. Id.

148. See Kristof, supra note 44 , at A1.

149. Lucie White, Quality Childcare for Low Income Families: Despair, Impasse, Improvisation, in HARD LABOR: WOMEN AND WORK IN THE POST WELFARE ERA 116 (Joel F. Handler \& Lucie White eds., 1999).

150. See id.

151. See id.

152. See id.

153. See id.

154. See id.

155. See id.

156. See id.

157. Id. The United States is not the Third World, and Williamston, despite her impossible circumstances, has well above the $\$ 800$ per year income. See id. This income level would place her in what the United Nations considers the world's "middle class." Yet just as there is a developed world within the developing world, see infra Part II.A.2.b. describing the Intercontinental Hotel, there is a developing world within the developed world. Fran Ansley, Saskia Sassen, and others have provided us with vivid accounts of those who live there. See also Hope Lewis, Lionheart Gals Facing the Dragon: The Human Rights of Inter/National Black Women in the United States, 76 OR. L. Rev. 567 (1997); 


\section{d. A Young Girl in Thailand 158}

A thirteen-year old girl-who looks ten or eleven-gazes up at the photographer from her homework. ${ }^{159}$ She is a former prostitute at a rehabilitation center in Cambodia. ${ }^{160}$ She says she was sold to a brothel when she was nine, but she was able to escape two months ago. ${ }^{161}$ The owners of the other brothels described in the article have purchased or kidnapped girl children in order to satisfy the increasing demand for ever younger sexual partners. ${ }^{162}$ The businessmen, the managers and representatives of the MNCs who support the lucrative "sex tourism" trade"163 believe that younger girls are less likely to be infected with AIDS or other sexually transmitted diseases. This is not always true. ${ }^{164}$

MCAFEE, supra note 44 , at $245-48$ (discussing the effects of privatization and deregulation in industrialized nations on the poor).

158. See Nicholas D. Kristof, Asian Childhoods Sacrificed to Prosperity's Lust, N.Y. TIMES, Apr. 14, 1996, at 1 (showing a snapshot of two young prostitutes). While a significant number of the approximately 250 million children working are girls, a full discussion of child labor is beyond the scope of this paper. For useful introductions, see generally INTERNATIONAL LABOUR ORGANIZATION (ILO), CHILD LABOUR: TARGETING THE INTOLERABLE (1996); UNICEF, Shadowy Figures, in THE STATE OF THE WORLD'S CHILDREN (1997); Katherine Cox, The Inevitability of Nimble Fingers? Law, Development, and Child Labor, 32 VAND. J. TRANSNAT'L L. 115, 12829 (1999).

159. See Kristof, supra note 158 , at 1.

160. See id.

161. See id.

162. See id. Slavery is a jus cogens violation of customary international law, and it is the focus of several conventions. See, e.g., International Convention to Suppress the Slave Trade and Slavery, Sept. 25, 1926, 46 Stat. 2183; Supplementary Convention on the Abolition of Slavery, the Slave Trade, and Institutions and Practices Similar to Slavery, Sept. 7, 1956, 18 U.S.T. 3201; ILO Convention No. 29 (Forced Labour Convention); ILO Convention No. 105 (Abolition of Forced Labour Convention). The traffic in women is a major business in many parts of the world. See, e.g., Michael Specter, Traffickers' New Cargo: Naïve Slavic Women, N.Y. TIMES, Jan. 11, 1998, at Al. For an overview of contemporary forms of slavery, see generally ORGANIZATION FOR ECON. COOPERATION \& DEV., TRADE, EMPLOYMENT AND LABOUR STANDARDS: A STUDY OF CORE WORKERS' RIGHTS AND INTERNATIONAL TRADE (1996); ASIA WATCH WOMEN'S RIGHTS PROJECT, A MODERN FORM OF SLAVERY (1993). See also Report of the Special Rapporteur on the State of Children, Child Prostitution and Child Pornography, U.N. GAOR, 49th Sess., Agenda Item 1010, at 16, U.N. Doc. A/49/478 (1994).

163. See generally SIRIPORN SKROBANEK ET AL., THE TRAFFIC IN WOMEN: HUMAN REalities of the InTERnational SeX TRADE (1997); THANH-Dam TRUONG, SEX, MonEY AND MORALITY: PROSTITUTION AND TOURISM IN SOUTHEAST ASIA (1990); BISHOP \& ROBINSON, supra note 62; THE SEX SECTOR: THE ECONOMIC AND SOCIAL BASES OF PROSTITUTION IN SOUTHEAST ASIA (1998) (describing the important role of the commercial sex industry in the social, economic and political life of Southeast Asia).

164. See Kristof, supra note 158 , at 1. 


\section{THE FAILURE OF Classic INTERNATIONAL LAW}

As defined in the Restatement of the Foreign Relations Law, "international law ... consists of rules and principles of general application dealing with the conduct of states and of international organizations and with their relations inter se, as well as with some of their relations with persons, whether natural or juridical."165 Under the classic conception, sovereign states join together to craft an international legal system to further their shared objectives. ${ }^{166}$ Some would argue that international law is doing precisely what it should-facilitating trade, assuring that MNCs are protected against expropriation, ${ }^{167}$ and assuring access to international dispute resolution procedures and fora, as well as to global markets.

It is beyond dispute, however, that international law should also protect the human rights of women within those states, including their economic, social, and cultural rights. ${ }^{168}$ But international law has failed women in at least two distinct but overlapping ways, both grounded in its failure to fully and effectively incorporate human rights law. First, on the state level, it has failed to prevent the widespread deprivation of human rights, caused by shredded safety nets, environmental degradation, and other byproducts of globalization, or to alleviate the resultant human suffering. ${ }^{169}$ Although the vast majority of states have ratified the International Covenant on Economic, Social and Cultural Rights (the Economic Covenant), ${ }^{170}$ for example, this has not deterred them from embracing policies that as a practical matter deny economic rights to massive segments of their own populations.

165. RESTATEMENT (THIRD) OF FOREIGN RELATIONS LAW § 101 (1987).

166. See FALK, supra note 14, at 1 (arguing that the modernist framework, predicated on "the collected benefit of each state pursuing its own particular interests," is no longer viable).

167. See SASSEN, supra note 2, at 14 (noting that "[f]irms operating transnationally need to ensure the functions traditionally exercised by the state in the national realm of the economy, such as guaranteeing property rights and contracts").

168. This is explicitly set out in international treaties. See, e.g., U.N. CHARTER arts. 55 \& 56; International Covenant on Economic, Social and Cultural Rights, Dec. 19, 1976, 993 U.N.T.S. 3 (entered into force Jan. 3, 1976) [hereinafter Economic Covenant]; International Covenant on Civil and Political Rights, Dec. 19, 1966, 999 U.N.T.S. 171 (entered into force Mar. 23, 1976) [hereinafter Civil Covenant]. It is also set out in customary international law. See, e.g., RESTATEMENT (THIRD) OF FOREIGN RELATIONS LAW \$ $701 \mathrm{cmt}$. e.

169. See Maastricht Guidelines, supra note 33 , at $696-97$ (discussing violations of commission and omission).

170. See Economic Covenant, supra note 168; see also infra note 197 (noting that 141 states have ratified the Economic Covenant). 
Second, international law has failed to compel even the most basic recognition of human rights on the part of the Major Players, ${ }^{171}$ that is, the non-state actors who are in fact the principal agents of globalization. Indeed, international law has failed even to bring MNCs and investment firms into the international system as participants.

\section{A. International Human Rights Law}

\section{The System}

The conventional story is that international human rights law arose from the ashes of World War II, a resounding "Never againl" to the atrocities of the Nazis. It is well known that the United States played a leading role in the promulgation and adoption of the early human rights instruments. The International Bill of Rights is grounded in Franklin Delano Roosevelt's "four freedoms," and the International Covenant on Civil and Political Rights (Civil Covenant) ${ }^{\mathbf{1 7 2}}$ closely tracks the U.S. Bill of Rights. ${ }^{173}$ Early U.S. support and the growing appeal of the "human rights idea," however, did not mean that the international community was ready to adopt human rights law as law. In fact, the ready acceptance of the Universal Declaration of Human Rights (Universal Declaration) ${ }^{\mathbf{1 7 4}}$ was predicated on the tacit understanding that it was unenforceable.

It was also grounded in a hopeful, if not naive, view of the law. Rights consciousness in the United States is redundantly embedded in our law and politics, ${ }^{175}$ starting with the earliest colonists from Great Britain.176 The Bill of Rights acquired the force of law because it was embedded in the Constitution, supported by a carefully constructed set of checks and balances, and firmly rooted in U.S. political tradition. ${ }^{\mathbf{1 7 7}}$ In addition,

171. As noted above, this refers to banks and investment firms, MNCs, and IOs. See supra notes 10-12 and accompanying text.

172. See Civil Covenant, supra note 168.

173. See LOUIS HENKIN, THE AGE OF RIGHTS 152-53 (1990).

174. G.A. Res. 217A, U.N. GAOR, 3d Sess., at 71, U.N. Doc. A/810 (1948).

175. Western Europe, of course, claimed a similar tradition and, in fact, recommitted to that tradition in the series of legal instruments establishing the European Community. I focus here on the United States because of its relative importance in globalization and because I assume my readers are more familiar with rights in the United States.

176. See JaCK N. RaKove, ORIGinal MEANings: POlitics and IDEAS in THE MAKING OF THE CONSTITUTION 295 (1996) (describing the rights consciousness among the colonists).

177. This included the earliest workable mechanisms for democratic accountability on the part of the executive and the legislature. See generally 
crucially, the Constitution was buttressed by a strong, independent judiciary. 178 Even so, it should be recalled, it took over a hundred years and a Civil War to produce Americans who "[took] rights seriously." 179

No analogs existed on the international level in 1948, obviously, and very few could be found on the national level outside of western Europe. International law lacks the checks and balances we take for granted in U.S. law. ${ }^{180}$ Whatever accountability has been provided by our concededly imperfect democracy is absent in the international sphere. ${ }^{181}$ Similarly, mechanisms for rights enforcement were virtually nonexistent on the international level and quite limited on the national level. It soon became clear, moreover, that "universal" human rights were not universal at all. 182

The Cold War gave human rights law a fatal chill in its infancy. As noted above, in order to facilitate consensus, the states had agreed from the beginning that the Universal Declaration was merely aspirational and that a legally binding instrument would be drafted later. ${ }^{183}$ In 1952, however, the U.N.

Michael Kammen, A Machine That Would Go of Itself: the Constitution in AMERICAN CULTURE (1986).

178. For a concise reprisal of "what we owe to John Marshall" in this context, see HENKIN, supra note 173, at 90.

179. RONALD DWORKIN, TAKING RIGHTS SERIOUSLY 184 (1977). Indeed, as Brown v. Board of Educ., 347 U.S. 483 (1954), was to vividly bring home, the United States itself was not that rights conscious in the 1950s. See generally Ruth Gordon, Growing Constitutions, 1 U. PA. J. CoNST. L. 528, 530 (1999) (arguing that "constitutions and laws should reflect and be derived from the cultural norms in which they must endure").

180. A rough political system of checks and balances was provided during the Cold War by the tension between the Western powers and the Soviets, which gave some leverage to the non-aligned states. It also froze the U.N. Security Council and hamstrung the International Court of Justice (ICJ). See, e.g., José E. Alvarez, The Once and Future Security Council, 18 WASH. Q. 3 (1995).

181. The U.N. General Assembly never purported to be a representative system and democracy remains a relatively new idea in many states. See generally infra notes $189-90$ and accompanying authorities.

182. As Hilary Charlesworth notes, "International law asserts a generality and universality that can appear strikingly incongruous in an international community made up of almost two hundred different nationalities and many more cultural, religious, linguistic and ethnic groups.” Charlesworth, supra note 94 , at 383.

183. See Commission to Study the ORG. OF PEACE, 2 BuILDing PEACE: RePortS OF THE COMMISSION TO STUDY THE ORGANIZATION OF PEACE 1939-1977, at 641 (1973). For a detailed description of the drafts, recommendations, and problems faced by the Commission on Human Rights, which had been requested to draft a Covenant by the General Assembly, see Matthew C. R. CRAven, The International Covenant on ECONOMIC, SOCLAL AND CULTURAL RIGHTS: A PERSPECTIVE ON ITS DEVELOPMENT 17-21 (1995). For an insightful explanation of the futility of producing an instrument that was "without political and cultural allegiances," see Dianne Otto, Rethinking the "Universality" of Human Rights Law, 29 COLUM. HUM. RTS. L. REV. 1, 7 (1997). 
General Assembly decided that two instruments would be necessary "because of the East/West split and the ideological disagreement over the value of socioeconomic rights." 184 The bifurcation of rights into two Covenants was further justified by differences in "the nature of the legal obligation and the systems of supervision that could be imposed."185

This bifurcation allowed states to reject rights incompatible with their own ideologies. ${ }^{186}$ Although the former Soviet Bloc states have ratified the Civil and Political Covenant, ${ }^{187}$ the United States-the most powerful country in the world-still refuses to ratify the Economic Covenant. ${ }^{188}$ Thus, while the international community continues to insist on the interdependence and equality of economic rights and civil/political rights, ${ }^{189}$ U.S. rejection of economic rights effectively reduces this to mere rhetoric. ${ }^{190}$

184. David P. Forsythe, Book Review, 8 HUM. RTs. Q. 540 (1986); see also JOHN P. HUMPHREY, HUMAN RIGHTS AND THE UNITED NATIONS: A GREAT ADVENTURE 144 (1984). For a description of the "complete reversal of its original position" by the General Assembly, pursuant to which it requested the Commission to draft two covenants on human rights, see G.A. Res. 543, U.N. GAOR., 6th Sess., Supp. No. 20, at 36, U.N. Doc. A/2119 (1952). See also Barbara Stark, United States' Ratification of the International Covenant on Economic, Social and Cultural Rights, in THE UNITED STATES AND HUMAN RIGHTS: LOOKING INWARD AND OUTWARD (David Forsythe ed., 1999).

185. D. J. HaRRIS, CaSES AND Materials ON INTERnational LaW 666 (4th ed. 1991).

186. “No matter how often the United Nations ... a affirmed and reiterated the interrelation, interdependence, and indivisibility of all human rights, different sets of countries, with different ideologies and social organizations, have always given priority to one category over the other ...." Alves, supra note 10, at 498.

187. See International Covenant on Civil and Political Rights (visited Apr. 6, 2000) <http://www1.umn.edu/humanrts/instree/b3ccpr.htm>.

188. See Philip Alston, U.S. Ratification of the Covenant on Economic, Social and Cultural Rights: The Need for an Entirely New Strategy, 84 AM. J. INT'L L. 365, 372 (1990) (describing strategy of "simply defining economic rights out of existence").

189. See Indivisibility and Interdependence of Economic, Social, Cultural, Civil and Political Rights, G.A. Res. 44/130, U.N. GAOR, 44th Sess., Supp. No. 49, at 209, U.N. Doc. A/RES/44/130 (1989) (accepted Dec. 15, 1989); see also Vienna Declaration and Programme of Action, 32 I.L.M. 1661, 1665 (1993).

190. See Statement to the World Conference on Human Rights on Behalf of the Committee on Economic, Social and Cultural Rights, U.N. Doc. E/1993/22, Annex III, reprinted in STEINER \& ALSTON, supra note 93, at 266. See also Henry Steiner, Introduction to BUSINESS AND HUMAN RIGHTS, supra note 20, at 11 (noting that "intergovernmental human rights institutions, and with some marked exceptions the NGOs as well, have given neither priority nor even concentrated attention to the problem of realizing worker rights"). 


\section{Economic Rights}

\section{a. On the State Level}

The Civil Covenant assures familiar negative rights, similar to those in the U.S. Constitution. The Economic Covenant, in contrast, recognizes positive rights, such as the rights to food, shelter, health care, and education. Just as the Civil Covenant is linked to free market democracy, and to the MNCs and investment firms that drive it, ${ }^{191}$ the Economic Covenant is linked to distributive justice for the most vulnerable, who are everywhere disproportionately female. Not surprisingly, most states are more responsive to the needs of MNCs and investment firms ${ }^{192}$ than to the needs of their poorest and least powerful constituents. ${ }^{193}$ The tenuousness of state commitment to the most vulnerable ${ }^{194}$ is reflected in the relative weakness of the Economic Covenant's implementation scheme.

Under Article 16 of the Economic Covenant, states file selfmonitoring reports with Committee on Economic, Social and Cultural Rights (CESCR). Under the leadership of Philip Alston, the system has been overhauled, streamlined, and rigorously focused. Nevertheless, Professor Alston is among the first to point out its still serious limitations. ${ }^{195}$ The Economic Covenant has

191. See supra Part II.A.1. Schlag points out, "[O]urs is a world . . . where the value of freedom implies at once the downfall of the Berlin wall and the imbibing of Pepsi." PIERRE SCHLAG, LAYING DOWN THE LAW: MYSTICISM, FETISHISM, AND THE AMERICAN LEgAL MIND 47 (1996). But see MCAFEE, supra note 44, at 155 (quoting Cary Harris, chief of the Dominican Republic's Economic Planning Division: "The United States is asking us to carry out [structural adjustment] policies under a democracy that really require dictatorship. Capitalism and democracy-it's a terrible mix.").

192. See supra note 31 (describing then-Governor Clinton's dinner with then-chief of Goldman Sachs Robert Rubin).

193. This reflects realpolitik. As Elizabeth Iglesias explains, "[T]he welfare state cannot narrow the gap between rich and poor without the power to impose real redistribution on economic elites .... Without that power, any redistributive policies will come inevitably at the expense of macroeconomic health because they will be financed through inflationary spending rather than through real redistribution." Elizabeth M. Iglesias, International Law, Human Rights, and LatCrit Theory, 28 U. MIAMI INTER-AM. L. REV. 177, 200 n.24 (1997).

194. See, e.g., Standing, supra note 44 , at 584 (describing "an erosion in the legitimacy of the welfare systems of industrialized countries"). But see Voters All Over Take the Wheel from Conservatives, N.Y. TIMES, Jan. 31, 1999, § 4, at 1 (discussing the commitment to social safety nets of newly-elected leaders in Western Europe).

195. See, e.g., Philip Alston, The Committee on Economic, Social and Cultural Rights, in THE UnITED NATIONS AND HUMAN RIGHTS: A CRITICAL APPRAISAl 473 (Philip Alston ed., 1992). 
had its most success where it has built on, and reinforced, extant domestic norms. ${ }^{196}$ It has had little effect elsewhere. ${ }^{197}$

But it was never expected that human rights, especially economic rights, were to be implemented or effectuated on the international level. Rather, it was always assumed that they were primarily the responsibility of national governments. ${ }^{198}$ Although virtually all of the states that have been recipients of IMF or World Bank loans have ratified the Economic Covenant, ${ }^{199}$ not one has rejected an SAP on the ground that it is barred by its ratification of the Economic Covenant from slashing domestic safety nets. ${ }^{200}$ Nor has any state relied on the Economic Covenant to insist that MNCs set wages at a level sufficient to assure an adequate standard of living, ${ }^{201}$ as set out in Article 11. Nor has any state relied on the Economic Covenant to draft-and to insist that MNCs comply with-environmental standards necessary to preserve the right to health set out in Article 12.

Nor can any state realistically be expected to interpose the Economic Covenant. These states are scrambling for a dropping percentage of the global GNP. Their currencies are falling. They cannot say "no" to capital. Rather, they find themselves in a desperate race to the bottom to bring some money into their impoverished countries.

196. "If . . . in a given context, values are ontologically deep-for instance, if they are sedimented cultural formations that constitute the very way in which our social and intellectual lives are fashioned-then engaging in value-talk might well be not only intellectually interesting, but even morally or politically important." SCHLAG, supra note 191, at 51 .

197. The Economic Covenant has been ratified by 141 states. See International Covenant on Economic, Social and Cultural Rights (visited Apr. 6, 2000) <www1.umn.edu/humanrts/instree/b2esc.htm>. It remains the poor relation in the U.N. system.

198. Germany, the Netherlands, France, Spain, Switzerland, and Turkey are among those states that have incorporated some of the provisions of the European Convention on Human Rights into their own domestic laws. See SASSEN, supra note 2 , at 93.

199. See International Monetary Fund, Fund Credit Outstanding, as at Aug. 31, 1999 (visited Apr. 6, 2000) <www.imf.org/external/np/tre/tad/excred2.cfm>; WORLD BANK, IBRD AND IDA CUMULATIVE LENDING BY COUNTRY, 1999 ANNUAL REPORT, app. 13 at 219 (1999).

200. This is explicitly cited as a violation of the Economic Covenant in the Maastricht Guidelines, supra note 33, at 697. See also Tzannatos, supra note 4, at 567-68 ("[W]omen now face a great risk of poverty as services that were traditionally borne by enterprises are now lost (such as daycare, child allowances, and family leave)").

201. This is also a violation under the Maastricht Guidelines, supra note 33, at 698 . 


\section{b. Non-State Actors}

Although IOs were originally created by member states and still remain dependent on states for support, in many respects they have become autonomous. The other Major Players-that is, MNCs and investment firms-while nominally subject to state law, in fact may be so much wealthier than the states to which they are subject that they can either buy the kind of law they like or go shopping elsewhere. ${ }^{202}$

i. International Organizations (IOs)

The international institutions that many believe responsible for much of the pain of globalization are not directly subject to human rights law because they are not states. ${ }^{203}$ Thus, the $\mathrm{IMF}^{204}$ the World Bank, ${ }^{205}$ and the WTO ${ }^{206}$ are free to ignore the Economic Covenant as they go about setting the conditions for loans and establishing trade regulations. ${ }^{207}$ An inspection panel was established in 1994 to assure that the World Bank complies with its own policies. 208 Inspections can be triggered by affected individuals and groups. ${ }^{209}$ The impact on economic rights is an

202. See Victor Dankwa et al., Commentary to the Maastricht Guidelines on Violations of Economic, Social and Cultural Rights, 20 HUM. RTS. Q. 705, 724 (1998).

203. But see Maastricht Guidelines, supra note 33, at 698 (IOs are subject to ICESCR because of their member states' obligations).

204. See Margaret Conklin \& Daphne Davidson, The IMF and Economic and Social Human Rights: A Case Study of Argentina, 1958-1985, 8 HUM. RTS. Q. 227 (1986).

205. For a cogent critique of World Bank policies, see Elizabeth M. Iglesias, Human Rights in International Economic Law: Locating Latinas/os in the Linkage Debates, 28 U. MIAMI INTER-AM. L. REV. 361, 374 (1997). See generally James C. $\mathrm{N}$. Paul, The Human Right to Development: Its Meaning \& Importance, $25 \mathrm{~J}$. MARSHALL L. REV. 235 (1992).

206. See, e.g., G. Richard Shell, Trade Legalism and International Relations Theory: An Analysis of the World Trade Organization, 44 DUKE L. J. 829 (1995); see also Steiner, supra note 190, at 10 (noting the resistance to "a social clause that would condition international trade privileges on respect for basic worker rights in the WTO").

207. Guideline 19 of the Maastricht Guidelines emphasizes that it is the duty of IO member states to assure IO compliance with ICESCR. See Dankwa et al., supra note 33, at 724. See generally GRAY, supra note 10, at 1-2 (arguing that the "overriding objective" of the WTO and the IMF is to "free economic life from social and political control").

208. See International Bank for Reconstruction and Development/ International Development Association, Inspection Panel Operating Procedures, Aug. 19, 1994, 34 I.L.M. 503, 510 (1995). For an excellent overview, see Ellen Hey, The World Bank Inspection Panel: Towards the Recognition of a New Legally Relevant Relationship in International Law, 2 HOFSTRA L. \& POL'Y SYMP. 61 (1997).

209. See Hey, supra note 208 , at 65-74. 
open question. 210 While such mechanisms could facilitate transparency, IOs do not control the investment firms that in fact control the lion's share of foreign direct investment (FDI), once the IMF has primed the pump. ${ }^{211}$

\section{ii. Multinational Corporations (MNCs)}

Under existing international law, $\mathrm{MNCs}^{212}$ are free to enter into any legal relationships that do not violate national laws. ${ }^{213}$ National laws that are particularly relevant in this context, such as labor laws regulating wages and hours, working conditions, occupational safety and health, and child labor, as well as human rights laws addressing discrimination in the workplace, are generally not enforceable extraterritorially. ${ }^{214}$ That is, a company can usually avoid the impact of these laws by locating abroad. Even when a state explicitly extends the application of such laws extraterritorially, 215 the impact has been limited under wellestablished principles of international jurisdiction. ${ }^{216}$

210. See, e.g., BRAIDOTTI ET AL., supra note 107, at 139 (explaining that the IMF and World Bank have used an accounting method that excluded the whole area of women's activities from the definition of economics. While military production is priced and perceived as contributing to economic growth, no value is attributed to women's household labour, or to peace, individual and social wellbeing, or the health of the environment.").

211. Treasury Secretary Rubin, along with the G7, urged the IMF to amend its Charter to allow greater liberalization. See Kristof \& Sanger, supra note 26, at A1.

212. There are different types of MNCs: (1) MNCs that use a country for outsourcing because of its cheap labor; (2) MNCs, such as Coke or McDonald's, who view the local market as their goal; and (3) MNCs dependent on investors who "vote with their feet and think the human rights business is not a part of their obligation." BUSINESS AND HUMAN RIGHTS, supra note 20, at 29 (remarks of Li Lu).

213. This includes, of course, national laws enacted pursuant to international law or Community law. MNCs can insulate themselves from the impact of interest rate changes through derivatives (i.e., futures, swaps, and options). See SASSEN, supra note 2, at 45. For a thoughtful analysis of corporate nationality in a global economy, see Linda A. Mabry, Multinational Corporations and U.S. Technology Policy: Rethinking the Concept of Corporate Nationality, 87 GEO. L. J. 563 (1999).

214. But see Generalized System of Preferences Renewal Act of 1984, 19 U.S.C.A. § 2461 (West 1999); 19 U.S.C.A. § 2467(4) (West 1999) (defining "internationally recognized worker rights"); 22 U.S.C.A. $\$ 191$ a(a)(1) (West 1999) (repealed).

215. The U.S. Congress could have done so following the Aramco case regarding Title VII, for example. See Equal Employment Opportunity Comm'n $v$. Arabian American Oil Co., 499 U.S. 244 (1991).

216. See RESTATEMENT (THIRD) OF FOREIGN RELATIONS LAW § 414. For a rigorous critique of U.S. statutes conditioning trade relations on "foreign compliance with unilaterally designed labor rights," see Iglesias, supra note 205, at 366-69. 
While virtually all states, and even most MNCs, would agree on the need for "harmonization of what are now unpredictable national laws and regulations, ${ }^{n 17}$ this coordination has been impossible to achieve. The capital-importing states where MNCs locate their factories are generally unable, or unwilling, to impose restrictions. Indeed, they have gone to extraordinary lengths to attract foreign capital, rescinding or suspending existing laws, often at the expense of an already marginal standard of living.

International law has no mechanisms or procedures and precious little theory to address this problem. 218 In fact, doing so would require major and rapid innovation in a system notorious for its glacial rate of change. One suggestion, for example, might be to recognize MNCs as having legal personality, at least for some purposes.219 Thus, they would become subjects of international law, participating in its creation and development, and capable of entering into binding multilateral agreements. But states continue to resist.220 MNCs would have dubious legitimacy,221 moreover, in an international system based on political control over territory and population. ${ }^{222}$

Some commentators have suggested, as an alternative, that MNCs be controlled through codes of conduct adopted by states, MNCs themselves, or both. These include specialized codes promulgated by the ILO as well as more general codes, such as the Model Business Principles endorsed by the Clinton

217. Arzt \& Lukashuk, supra note 10, at 170.

218. See Steiner, supra note 190, at 9-10 (exploring incentives and sanctions for inducing profit-seeking enterprises to further human rights). See also Dau-Schmidt, supra note 7 , at 58 (urging international conventions to encourage initiatives to educate women and prohibit their exploitation).

219. This has already been done in the Iran-United States Claims Tribunal, established by the Algiers Declaration of 1981. See Arzt \& Lukashuk, supra note 10, at 167. See also Shell, supra note 207, at 922-23 (arguing that MNCs as well as social interest groups should participate in WTO policymaking).

220. Developing states "would never allow [MNCs] to play an autonomous role in international affairs. Even Western countries are reluctant to grant them international standing; they prefer to keep them under their control-of course, to the extent that this is possible." Arzt 80 Lukashuk, supra note 10, at 168 (citing Cassese). See also Jonathan I. Charney, Transnational Corporations and Developing Public International Law, 1983 DUKE L. J. 748 (describing limited roles of MNCs). As Oscar Schachter notes, "[a] new international business class tends to identify itself with the global aims of its transnational companies rather than with the political objectives of its particular countries." Schachter, supra note 64 , at 10 .

221. See James E. Hickey, Jr., The Source of International Legal Personality in the 21st Century, 2 HOFSTRA L. \& POL'Y SYMP. 1, 12-14 (1997).

222. See generally RESTATEMENT (THIRD) OF FOREIGN RELATIONS LAW § 201 (defining "state" as "an entity that has a defined territory and a permanent population"). 
administration. ${ }^{223}$ Western states generally have resisted adoption of such codes of conduct as binding. ${ }^{224}$ Even if they were adopted, however, they would be binding only on states. ${ }^{225}$ While codes may be binding on MNCs that voluntarily adopt them, their effectiveness remains to be proven.

\section{iii. Investment Firms}

The global economy is not dominated by cars and steel and wheat, but by stocks and bonds and currencies. As of 1995, mutual funds, pension funds, and other institutional investors controlled $\$ 20$ trillion in assets-ten times the figure of 1980.226 The global economy is dominated by investment capital, and human rights law is legally irrelevant.

No one controls financial markets. ${ }^{227}$ States can govern their own banks and investment firms, but no international law requires them to do so. The Thai government, for example, sent a letter to Allan Greenspan, Chair of the Federal Reserve, complaining that U.S. hedge funds and banks were investing billions to destabilize their country. Greenspan had an aide send

223. See U.S. Department of Commerce, International Trade Commission, <www.ita.doc.gov/bgp/model.html> (visited Mar. 14, 2000). A clearinghouse for codes is maintained by the U.S. International Trade Administration at <www.ita.doc.gov/bgp/clearing.html> (visited Mar. 19, 2000). See generally STEINER \& ALSTON, supra note 93, at 870-73 (discussing codes of conduct for foreign operations of U.S. businesses).

224. In 1976, the U.S . . agreed with the other members of the OECD on a code for multinational enterprises ..... It was easy for other OECD governments to sign, because it had no binding effect on them. Some lawyers might think it was agreed on in order to create norms, but the governments knew better. They just took for granted that it wouldn't commit anybody.

BUSINESS AND HUMAN RIGHTS, supra note 20, at 23 (remarks of Ray Vernon).

225. See supra Part II.A.2.b.

226. See Kristof \& Wyatt, supra note 24 , at A1.

227. [S]hifts in the capital market are leading to a situation in which the model for investment is no longer the large, international, American company investing to advance its own particular interests in a country ... . Now [we] see more independent capital . . . going directly into foreign markets. If you take, for example, Brazil or India, more than half of today's foreign direct investment is probably independent capital.

BUSINESS AND HUMAN RIGHTS, supra note 20, at 25 (remarks of Bowman Cutter). Investors and banks rely on experts like Standard \& Poor and Moody. But scholars say that such services react rather than predict performance. See Kristof \& Wyatt, supra note 24, at A1. Capital can flee as quickly as it arrives, moreover. This is what happened in Thailand, where $\$ 16$ billion in 1996, up to $\$ 45$ billion in 1997, fled to banks in Switzerland, London, and New York. See id. 
a brief reply to the effect that such matters were better left to the market.228

Individual investors are, for the most part, oblivious. Mary Jo Paoni, for example, is a secretary in Illinois whose state pension fund bought shares in Thai international funds. ${ }^{229}$ She knew nothing of the Thai funds' investment in a ghost town outside Bangkok, a complex of twenty-four buildings, each almost thirty stories high. Indeed, Mrs. Paoni disapproves of the giddy investment sprees in Asia. "When things are tough," she said, "you don't start spending like a drunken sailor. There are some people who take risks, but not us."230

The relationship between investment capital and human rights raises complex issues. ${ }^{231}$ The critical point here is that those seeking to make investment capital responsive to human rights concerns cannot rely exclusively on the existing international legal system. To the extent such efforts depend on mobilizing this system, they have been-and are likely to continue to be-futile.

\section{B. The Roles of Lawyers}

In the classic conception, lawyers have played a critical role in generating and structuring international law, and will continue to do so. In the field of human rights, for example, lawyers helped draft the Universal Declaration ${ }^{232}$ and have assumed significant responsibility in its ongoing implementation, particularly with respect to civil and political rights. Lawyers focusing on economic rights, in striking contrast, often have been stymied by the theoretical problems of generating binding law regarding rights that are to be "progressively realized" and implemented through an unspecified and open-ended range of mechanisms. ${ }^{233}$ The practical problems, especially those posed

228. See Kristof \& Wyatt, supra note 24, at A1. A similar letter was sent to Greenspan's counterpart in Germany, who immediately replied, "Which of our banks?" Id.

229. See id.

230. Kristof \& Sanger, surpa note 26, at A1.

231. Experts refer to a need for a "new financial architecture," but proposals are "usually fairly small-bore." Kristof, supra note 44, at A1. The American Society of International Law is presently engaged in a comprehensive research project on "Human Rights and World Economic Law," under the direction of John Jackson and Frederick Abbott. AMERICAN SOCIETY OF INTERNATIONAL LAW, REPORT OF THE EXECUTIVE DIRECTOR, Oct. 30, 1999 at 8.

232. See LOUIS HENKIN ET AL., HUMAN RIGHTS 292 (discussing authorship of the Universal Declaration).

233. See Barbara Stark, The Other Half of the International Bill of Rights, in RECONCEIVING REALITY: WOMEN AND INTERNATIONAL LAW 19 (Dorinda Dallmeyer ed., 1993). 
by the lack of accountability on the part of the state, as well as non-state actors, have been even more daunting.

1. Theory: Better, Clearer, More

Human rights lawyers no longer attempt to find a theoretical justification for human rights law. ${ }^{234}$ Rather, it is assumed that consensus has been achieved. As Rorty observes, "foundationalist projects are outmoded. We see our task as a matter of making our own culture-the human rights culture-more self-conscious and more powerful, rather than of demonstrating its superiority to other cultures by an appeal to something transcultural."235 Thus, for most classic theorists, the major task now is to improve the system, to promulgate standards, to streamline procedures, and to assure better implementation.236 While dissent is recognized, it is generally either dismissed as the rhetoric of repressive regimes, ${ }^{237}$ or viewed as a form of loyal critique-that is, a complaint by those who support human rights law but want it to be more inclusive or more effective. ${ }^{238}$

But the consensus ostensibly achieved with respect to human rights does not in fact extend to economic rights, although there has been little serious effort to refute economic rights in theory. Rather, the tacit argument is that economic rights are not rights in the sense that civil and political rights are. Rather, they are aspirations for a better way of life, and the best way of realizing them is through free market democracy. ${ }^{239}$

234. This was not always the case. See, e.g., LoUIS HENKIN, THE RIGHTS OF MAN TODAY (1978) (discussing efforts to ground human rights law in positivist law and natural law).

235. Rorty, supra note 94 , at 117 .

236. See, e.g., ABA CONFERENCE COMMEMORATING THE 50TH ANNIVERSARY OF THE UNIVERSAL DEClaRATION (1998) [hereinafter ABA CONFERENCE] ("The first 50 years we set standards, the next 50 years we will implement them."). Interestingly, the same approach is assumed to be viable for economic rights, notwithstanding the lack of supporting consensus. See, e.g., Michael Posner, Foreword: Human Rights and Non-governmental Organizations on the Eve of the Next Century, 66 FORDHAM L. REV. 627, 628 (1997) ("[T]o give practical meaning to economic and social rights . . . it is necessary to develop more precise definitions and standards for these rights ... [and] to develop enforcement strategies on both national and international levels").

237. See, e.g., HENKIN ET AL., supra note 232, at 1214 (on "maintaining the universality of human rights").

238. Cf. infra Part IV.C.2.

239. This is a corollary of the argument that the best way to further human rights in general is by promoting democracy. See John Norton Moore, Remarks, in ABA CONFERENCE, supra note 236; see also Edward B. Foley, The Elusive Quest for Global Justice, 66 FORDHAM L. REv. 249, 271 (1997) ("[T]he right to participate as an equal citizen in democratic elections is the most fundamental human right"). For a sober assessment of U.S. efforts to promote democracy abroad 


\section{Practice: Using the Law to Represent Clients}

As explained above, ${ }^{240}$ economic rights assure a bottom line to the extent domestic law incorporates economic rights law. In some states, lawyers can use domestic law to vindicate their clients' economic rights claims. Lawyers in India, for example, can file individual petitions on behalf of the poor. ${ }^{241}$ Lawyers in Spain can rely directly on the Economic Covenant, since the Spanish Constitution of 1978 accords the Covenant constitutional status. ${ }^{242}$ Where there is no relevant domestic law, lawyers can lobby, arguing that law should take economic rights into account for political as well as for legal reasons. ${ }^{243}$

Reliance on the Economic Covenant may be difficult, however, because it can be argued that whatever obligation it imposes is in fact being met. Article 2 of the Economic Covenant requires only that the state "progressively realize" economic rights. ${ }^{244}$ The narrowing wage differential between women and men, ${ }^{245}$ especially in conjunction with women's increased market participation, arguably demonstrates precisely the progressive realization required. ${ }^{246}$

during the 1980s and 1990s, see THOMAS CAROTHERS, Aiding DEMOCRACY ABROAD: THE LEARNING CURVE (1999).

240. See Part II.A.2.a.

241. See PAUL HUNT, REClaiming SOCIAL RightS: INTERNATIONAL AND COMPARATIVE PERSPECTIVES 154-55 (1996). See also P.N. Bhagwati, Judicial Activism and Public Interest Litigation, 23 Colum. J. TRANSNAT'L L. 561 (1985).

242. See Thomas Buergenthal, Modern Constitutions and Human Rights Treaties, 36 Colum. J. TRANSNAT'L L. 211, 212, 217 (1997) (noting that deference to human rights treaties is increasingly common in Western democracies.).

243. As Professor Alvarez suggests, "[R]ace critics may usefully remind government negotiators of the need to keep investment liberalization responsive to the desperate plight of the underclass in both FDI sending and receiving states as only this kind of liberalization is likely to survive the pressures of representative government." Alvarez, supra note 82, at 312 . Lobbying may also be part of the postmodern project. See, e.g., infra Part IV.B.-C. This is a distinction of degree, rather than kind. To the extent that such lobbying depends on and buttresses classic conceptions, such as those regarding the "pressures of representative government" to which Professor Alvarez refers, it is part of the classic project. To the extent such lobbying challenges those premises, by noting, for example, that representative government may well ignore those pressures, it is better characterized as postmodern.

244. Economic Covenant, supra note 168, art. 2.

245. See Part II.B.1.b.

246. But see Maastricht Guidelines, supra note 33 (ICESCR requires more); Philip Alston, The International Covenant on Economic, Social and Cultural Rights, in U.N. CENTER FOR HUMAN RIGHTS, MANUAL ON HUMAN RIGHTS REPORTING UNDER SIX MAJOR INTERNATIONAL HUMAN RIGHTS INSTRUMENTS, at 39,45 , U.N. Doc. HR/PUB/91/1 (1991). 


\section{The Position of Women}

1. Theory: "Equal" to Men

In addition to guaranteeing civil and political rights and recognizing economic, social, and cultural rights, ${ }^{247}$ the classic conception explicitly assures women's "equality" with men. ${ }^{248}$ The Economic Covenant emphasizes the importance of nondiscrimination on the basis of sex by reiterating it in two articles (Articles 2 and 3), and it supports the concept of affirmative action. ${ }^{249}$ The Civil Covenant assures women's civil rights, as well as access to the political process. Whatever rights men enjoy, in short, are to be equally available to women. Sometimes this may require affirmative action to bring historically subordinated women up to the starting line.

While feminists generally welcome the notion that women should not have less or fewer rights than men, some have criticized "equality" for incorporating a male norm-that is, for assuming that women should be like men and want what men want. Feminists have also criticized classic international law for excluding women as participants ${ }^{250}$ and for treating them more as passive objects than as active subjects of international law.

Classic international law has responded to many of these complaints. The Convention on the Elimination of All Forms of Discrimination Against Women (CEDAW) ${ }^{251}$ expands and clarifies the classic understanding of rights by specifying de facto as well as de jure application and by extending the prohibition against discrimination to private, as well as to state, actors. CEDAW also rejects the notion of a male norm by addressing human rights violations that are gender specific. ${ }^{252}$

While it is generally conceded that women in fact have been and still are subordinated, ${ }^{253}$ the assumption remains that the classic

247. See CRAVEN, supra note 183.

248. See supra Part III.A.1.

249. See CRAVEN, supra note 183, at 184-86 (concluding that while the travaux confirmed the legitimacy of affirmative action, there is little indication beyond Article 3 that it is required, although the focus throughout on vulnerable and disadvantaged groups is consistent with affirmative action).

250. See generally WOMEN, POLITICS, AND THE UNITED NATIONS (Anne Winslow ed., 1995) (describing efforts by feminists to organize women within the United Nations). See also HENKIN ET AL., supra note 232, at 390.

251. G.A. Res. 34/180, U.N. GAOR, 34th Sess., Supp. No. 46, at 193, U.N. Doc. A/34/46 (1980) (entered into force on Sept. 3, 1981).

252. See HENKIN ET AL., supra note 232 , at 370 .

253. See, e.g., STEINER \& ALSTON, supra note 93, at 887 ("Of the several blind spots in the development of the human rights movement from 1945 to the present, none is as striking as that movement's failure to give to violations of women's (human) rights the attention, and in some respects the priority, that they 
commitment to rights, especially civil and political rights, will change consciousness and norms over time. This commitment, the classic theorists argue, represents the best hope for improving the real conditions of women's lives. At the very least, it is preferable to traditions that pay lip service to women's "difference," while consigning them to second class status or worse. 254

\section{Practice: A "Better" World for Our Daughters}

A few states are willing to legislate gender equality that goes beyond accepted norms. ${ }^{255}$ Most states, however, have been content to legislate formal equality and the results have been mixed. In the absence of pervasive political commitment to women's rights, resources remain skewed. ${ }^{256}$ Moreover, attempts to impose human rights norms on traditional societies may backfire. ${ }^{257}$

Formal equality, in short, is not a panacea. In addition, notwithstanding the ambitious reach of CEDAW, human rights law still neglects many women's concerns, especially those relating to economic rights. ${ }^{258}$ The Thai girl is the only one in the snapshots, ${ }^{259}$ for example, with a legally cognizable claim. ${ }^{260}$

require"); see also HENKIN ET AL., supra note 232, at 359 (“[D]espite these legal guarantees, women have long experienced gross inequalities in the enjoyment of fundamental rights.").

254. See, e.g., THE QUALITY OF LIFE, supra note 34. But see Chandra Talpade Mohanty, Under Western Eyes: Feminist Scholarship and Colonial Discourses, in THIRD WORLD WOMEN AND THE POLITICS OF FEMINISM 51 (Chandra Talpade Mohanty et al. eds., 1991) (Western criticism is ethnocentric); NUSSBAUM, supra note 63, at 135 (noting that U.S. women perform worse than women in Barbados, Bahamas, Mexico, Belize, Bulgaria, Lesotho, Bangladesh, and many other states in the area of political representation).

255. Sweden and Norway, for example, have modified their family leave policies because men were not taking the leaves as often as women. To induce them to do so, these states changed the law so that a portion of the leave would be forfeited if not taken by both parents.

256. See supra Part II.B.

257. The attempts of Western feminists to impose bans on female genital surgeries are a conspicuous example. See, e.g., Hope Lewis, Between Irua and "Female Genital Mutilation": Feminist Human Rights Discourse and the Cultural Divide, 8 HARV. HUM. RTS. J. 1 (1995); Isabelle R. Gunning, Arrogant Perception, World-Traveling and Multicultural Feminism: The Case of Female Genital Surgeries, 23 COLUM. HUM. RTS. L. REV. 189 (1992).

258. See, e.g., Barbara Stark, The Economic Covenant as a Resource for Women, in WOMEN'S INTERNATIONAL HUMAN RIGHTS: A REFERENCE GUIDE 209 (Dorean Koenig \& Kelly Askin eds., 1999). It also fails to provide access to audiences capable of addressing these concerns. See, e.g., Rebecca J. Cook, State Responsibility for Violations of Women's Rights, 7 HARV. HUM. RTS. J. 125, 131 (1994).

259. See supra Part II.B.2. 


\section{THE POSSIBILITIES OF POSTMODERN INTERNATIONAL LAW}

\section{A. Postmodern International Law}

Postmodernism refers to at least three distinct but related conceptions. ${ }^{261}$ First, according to David Harvey,

[t]he most startling fact about postmodernism [is] its total acceptance of the ephemerality, fragmentation, discontinuity, and the chaotic .... But postmodernism responds to that fact in a very particular way. It does not try to transcend it, counteract it, or even to define the 'eternal and immutable' elements that might lie within it. Postmodernism swims, even wallows, in the fragmentary and the chaotic currents of change as if that is all there is. ${ }^{262}$

Second, philosopher Jean François Lyotard defines the postmodern simply as "incredulity toward metanarratives."263 Perhaps the major metanarrative to inspire postmodern incredulity is the Enlightenment and its credo that rational thought, the empirical method, and an ever-growing body of science will lead not only to human progress, but to human good.

Third, rather than abstract ideals, postmodernism is "rooted[] in daily life,"264 especially the commodification of culture. As J. M. Balkin puts it, postmodernism owes more to the shopping

260. Slavery is prohibited under international law. See supra note 162. It is also expressly barred by the Civil Covenant, supra note 168 , art. 8 , and the Economic Covenant, supra note 168, arts. 7, 10. Although Ofelia is under eighteen years old, which makes her a child under the Convention on the Rights of the Child, U.N. Doc. A/RES/44/25 (1989), under most interpretations by states as well as IOs, prohibitions against child labor do not apply to children over fifteen years old. See Cox, supra note 158, at 127. But see Sam Dillon, Sex Bias is Reported by U.S. at Border Plants in Mexico, N.Y. TIMES, Jan. 13, 1998, at A8 (U.S. Labor Department found that many U.S. plants in the maquiladoras forced pregnant workers to quit).

261. Ihab Hassan offers a schematic set of dichotomies, which suggests how postmodernism may be understood by comparing it to modernism:

modernism
semantics
metaphor
purpose
design
centering
narrative/grande histoire
metaphysics

postmodernism
rhetoric
metonym
play
chance
dispersal
anti-narrative/petite histoire
irony

IHAB Hassan, The POSTMOdern TURN: Essays in POSTMOdern Theory and Culture 91-92 (1987).

262. DAVID HARVEY, THE CONDITION OF POSTMODERNITY: AN ENQUIRY INTO THE ORIGINS OF CULTURAL CHANGE 44 (1989).

263. JEAN-FRANÇOIS LYOTARD, THE POSTMODERN CONDITION: A REPORT ON KNOWLEDGE at xxiv (Geoff Bennington \& Brian Massumi trans., 1984).

264. HARVEY, supra note 262, at 63. 
mall than to Lyotard, ${ }^{265}$ or, in Fredric Jameson's famous phrase, "postmodernism is the cultural logic of late capitalism."266

Unlike the conceptions that underlie and animate classic international law, the conceptions of postmodernity offer no unified, coherent approach to be fine-tuned to particular circumstances. They contemplate no metanarrative, no conception of human good to be universally espoused and ultimately achieved. ${ }^{267}$ There is no condemnation of the market, no ideal woman to be served, no ideal welfare system to be constructed to meet her needs. ${ }^{268}$ Thus, postmodernism is better suited to deconstructive than to reconstructive projects. ${ }^{269}$ For precisely these reasons, however, postmodernism offers more useful frameworks for economically subordinated women seeking to grapple with globalization. This Article does not suggest that human rights law be jettisoned. Rather, the argument here is that now, in the year 2000, most women are better served by postmodern approaches, emphasizing political rhetoric rather than legal semantics, ${ }^{270}$ and by the many performative roles ${ }^{271}$ of economic rights law as opposed to relying on its limited, even pinched, role as law.

\section{Fragmentation and Discontinuity}

Globalization, as noted above, is not a function of a discrete set of factors. Rather, it is a function of "chaotic currents of

265. See J. M. Balkin, What is a Postmodern Constitutionalism?, 90 MrCH. L. REv. 1966, 1976 (1992).

266. FRedric Jameson, Postmodernism, or, the Cultural logic of Late CAPITALISM 1 (1991).

267. "[O]ur postmodern age . . . has begun in a variety of discourses to question seriously the belief in unhampered progress and in the blessings of modernity .... HUYSSEN, supra note 19, at 56. But see HASSAN, supra note 261, at 89 ("WW]e can not simply rest . . on the assumption that postmodernism is antiformal, anarchic, or decreative; for though it is indeed all these, and despite its fanatic will to unmaking, it also contains the need to discover a unitary sensibility. $\left.{ }^{\prime}\right)$.

268. See generally Vasuki Nesiah, Toward a Feminist Internationality: A Critique of U.S. Feminist Legal Scholarship, 16 HARv. WOMEN'S L.J. 189 (1993) (discussing differences among women in the international context).

269. As Richard Falk has observed, postmodernism is "radically deconstructionist, destroying, if it can, all illusions that anything whatsoever can be singled out as truly significant." FALK, supra note 14, at 5 .

270. See HASSAN, supra note 261, at 91-92. Legal semantics refers to the typical process through which a legal theory is crafted to advance a client's claim. Political rhetoric, in contrast, refers to the range of persuasive arguments for new legal forms, such as a more transparent WTO process, that may be addressed to policymakers, grassroots groups, and other constituencies.

271. See supra note 15 and accompanying text (describing what Professor Schlag refers to as the "performative roles" of law-e.g., to persuade or justify, to identity or organize a political grouping or as a motivational orientation). 
change," and it can only be dealt with through a similarly "fragmentary" and "discontinu[ous]," ever-changing set of responses. ${ }^{272}$ Thus, from a postmodern perspective, the question is not how best to apply ILO frameworks in the context of the informal sector, but what do specific women need in specific contexts. The postmodernist is not frustrated by the flexible, fragmentary nature of recent labor trends. Rather, she recognizes that just as there is room for new workers in such a fast-moving system, there is room for new ad hoc approaches to economic rights.

There have been a proliferation of microcredit programs sponsored by U.N. agencies, such as UNIFEM, private aid organizations such as OXFAM, and individuals, including groups of women who pool their own meager resources to enable each other to make small capital investments, ${ }^{273}$ as well as "microbankers" like Muhammad Yunus. 274 He explains that he founded his microcredit bank in Bangladesh inspired by poor women, such as the stool maker who began each morning with a large stack of cane, and finished her work each evening with a somewhat smaller stack of stools. 275 She would return to the cane seller and trade stools for a new stack of cane and approximately two cents in Bangladesh currency. ${ }^{276}$ Yunus loaned her enough to buy one day's worth of cane, freeing her from the cane seller. ${ }^{277}$

\section{Incredulity Toward Metanarratives}

Like international human rights law, postmodernism is often linked to the discovery of the death camps after World War II. International human rights, as described supra, 278 responded by drafting new laws, drawing on the Enlightenment. Postmodernists such as Theodor Adorno, in contrast, questioned

272. See HARVEY, supra note 262, at 44; see also Sassen, supra note 4 , at 9 ("The current phase of the world economy is characterized by significant discontinuities with the preceding periods and radically new arrangements.").

273. But see BRAIDOTTI ET AL., supra note 107, at 78 (criticizing "small, women's programmes in 'female domains' (handicraft production, knitting, sewing, mother and child health care for example) [that] can easily be attached to ongoing development projects without challenging existing gender relations and patriarchal structures in society").

274. See generally MUHAMMED YUNUS, BANKER TO THE POOR (1998).

275. See id. at 47.

276. Id.

277. See id. at 50.

278. See supra Part III.A.1. 
the role of the Enlightenment project itself in the Holocaust. ${ }^{279}$ The "final solution" was not, after all, a barbarian rampage but an orderly, systematic, scientific program of genocide-authoritarian, bureaucratic, and perversely rational. 280

The dark side of the Enlightenment was Nietzsche's "will to power," the reification of reason and the march to a universal society. ${ }^{281}$ This was all too evident to Adorno in contemporary Stalinism and fascism. ${ }^{282}$ Crucially, the dangers are not limited to those particular totalizing cultures. Rather, the dark side of the Enlightenment can be seen in what Richard Falk describes as the

dirty hands of our own governing process when it comes to such matters as the unabated legacy of destruction directed at the indigenous peoples of our own continent, the moral scandal of financing and promoting terrorism in Central America, the still unacknowledged criminality of dropping atomic bombs on Hiroshima and Nagasaki and of preparing unabashedly for nuclear war, the incredible discrepancy between our overall affluence and

279. See Gillian Rose, The Melancholy Science: an InTroduction to the THOUGHT OF THEODOR W. ADORNO 19 (1978) ("Nietzsche, according to Adorno, refused 'complicity with the world' which . . . comes to mean rejecting the prevalent norms and values of society on the grounds that they have come to legitimise a society that in no way corresponds to them-they have become Ties." (footnote omitted)). See also THEODOR ADORNO \& MAX HORKHEIMER, DIALECTIC OF ENLIGHTENMENT (John Cummings trans., 1972). According to John Gray, the Enlightenment contemplated "the creation of a single worldwide civilization" and the United States, "the last great power to base its policies on this enlightenment thesis" seeks the global domination of democratic capitalism, a "single universal free market." GRAY, supra note 10, at 2. Santos argues that the law must be uncoupled from the state and recoupled with revolution (using the French Revolution as an example). See DE SOUSA SANTOS, supra note 14, at 104-105.

280. According to Rorty, the notion of humans as rational "accounts for the residual popularity of Kant's astonishing claim that sentimentality has nothing to do with morality, that there is something distinctively and transculturally human called the sense of moral obligation' which has nothing to do with love, friendship, trust, or social solidarity." Rorty, supra note 94, at 122 . Santos argues that law is the "alter ego" of science. DE SOUSA SANTOS, supra note 14 , at 4.

281. Nietzsche exposed the Enlightenment as the unity of reason and domination. See ROSE, supra note 279 , at 20 . In his brilliant and iconoclastic essay In the Wake of Empire, Nathaniel Berman links the surrender of Germany on May 8, 1945 to anti-French (anti-colonial) riots in Algeria. See Nathanial Berman, In the Wake of Empire, 14 AM. U. INT'L L. REv. 1515, 1521 (1999).

282. Both espoused noble ideas that masked a very different reality. Even supporters of human rights note a similar dichotomy between theory and practice. Alves describes a "deeply humanistic form of rational environmentalism, difficult to oppose, that now seems to prevail among all actors-no matter how sadly limited the implementation of its recommendations may have been so far." Alves, supra note 10, at 496 (emphasis added). 
the growing numbers of homeless and hungry persons scattered about our cities. ${ }^{283}$

The Enlightenment made man the center of the universe, but its "universal, objective, rational subject" is in fact a Western white man.284 Just as the Enlightenment promised utopia (but concealed the will to power of Western culture), free market democracy promises utopia, but conceals the will to power of late capitalism, ${ }^{285}$ which in fact values profits above human good. To the extent international human rights law supports and justifies free market democracy, it must be carefully scrutinized. Thus, postmodernism challenges Western hegemony, culturally and politically.

From a postmodern perspective, human rights law is not in itself a "good."286 Indeed, postmodernism rejects abstract notions of the good in favor of concrete, contextualized applications. ${ }^{287}$

283. FALK, supra note 14, at 10. See also Korematsu v. U.S., 323 U.S. 214 (1944) (upholding wartime order detaining U.S. citizens of Japanese descent in camps). This argument has particular salience in the international context, moreover, where efforts to hold the state accountable have so often been futile. See, e.g., Sanchez-Espinoza v. Reagan, 770 F.2d 202, 207 (D.C. Cir. 1985) (rejecting claim against the Reagan Administration for torts arising out of U.S. covert action in Nicaragua).

284. "At the center of the humanist creed lies the concept of the Western self." HUYSSEN, supra note 19, at 159. A corollary is the notion that "What [is] good for [America is] good for the world." Berman, supra note 281, at 1532 (quoting Abe Fortas).

Postmodernism questions the integrity, the coherence, and the actual identity of the humanist individual self . . . . For postmodernism, this humanist individual subject is a construction of texts, discourses, and institutions. The promise that this particular human agent would realize freedom, autonomy, etc., has turned out to be just so much Kant.

SCHLAG, supra note 191 , at 24.

285. Cf. Eve Darian-Smith, Power in Paradise: The Political Implications of Santos's Utopia, 23 L. \& Soc. INQUIRY 81, 86 (1998) (concluding that Santos's goal “is, above all, modernist: it conceals relations of power in the march toward emancipation of the oppressed").

286. See SCHLAG, supra note 191 , at 3 .

For Nietzsche, the death of God meant not only that the Judeo-Christian God was dead, but that the entire metaphysics implicated in his reign died as well. Hence, once God died, so did all the other God-substitutes (reason, law, morality) that might have been or might yet be enshrined in his metaphysical place.

Id. at 6.

287. See, e.g., Clark, supra note 44 , at 45 ("Transnational agents and agencies can avoid taking responsibility for the consequences of their decisions because abstract principles like the free market are privileged over concrete local results."). Cf. Gordon, supra note 179, at 530 ("Constitutions can flourish and succeed only if they are firmly planted in the cultural soil from which they gain legitimacy."). These concrete applications are assessed through a critical process 
Thus, the question is not how women can realize their human rights within an implied context of free market democracy, not how the law can help women become market players equal to men, but how women can use the law to further their own objectives. This shifts the focus from definitions of equality, and the hidden subject who is doing the defining, to questions of political strategy 288 - how variously situated women can use economic rights law. 289

Incredulity toward metanarratives has further consequences in the context of economic rights. First, it exposes the assumption of homogeneity on which much of economic rights law is predicated. ${ }^{290}$ Second, it challenges the assumptions underlying massive development projects, like those of the 1970s and $1980 \mathrm{~s}, 291$ in favor of smaller, locally controlled projects that, as the development community now recognizes, not only risk less but are more likely to have a positive impact. ${ }^{292}$

Third, this incredulity suggests a shift in focus from theorybuilding to storytelling. Stories are necessary if we are to take the widespread deprivation of economic rights seriously. ${ }^{293}$ Such

of standpoint epistemology. See Katherine T. Bartlett, Feminist Legal Methods, 103 HARV. L. REV. 829, 836 (1990). Thus, moral philosophy becomes irrelevant. See Rorty, supra note 94 , at 116.

288. "An imagined community of feminist interests does not imply homogeneity, a single set of feminist concerns, but rather a strategic, political alliance." Charlesworth, supra note 94 , at 384.

289. This version of postmodernism incorporates a form of pragmatism, see infra text accompanying notes 298-301, but is distinguishable because of its reliance on a "critical process of standpoint epistomology." Bartlett, supra note 287, at 836. But see Stephen M. Feldman, Playing With the Pieces: Postmodernism in the Lawyer's Toolbox, 85 VA. L. Rev. 151, 152 (1999) (discussing how modernist scholars have "accept[ed] [the] postmodern insight" that "all substantive ends and legal processes reflect distinctive cultural values and social positions" but "domesticate [such] postmodern insights by putting them in the lawyer's toolbox, to be taken out and used only when needed ${ }^{n}$ ).

290. The paradigm for such rights is usually found in the welfare states of Western Europe, where the populations, at least until fairly recently, were relatively homogenous. For a perceptive analysis of the ways in which human rights may be tailored to specific cultures, see Christina M. Cerna, Universality of Human Rights and Cultural Diversity: Implementation of Human Rights in Different Socio-Cultural Contexts, 16 HUM. RTS. Q. 740 (1994).

291. See, e.g., BRAIDOTTI ET AL., supra note 107, at 109 (explaining how "large-scale projects [such] as dams, nuclear power plants . . . have displaced people from their land with devastating effects").

292. See Paul, supra note 205, at 257-58.

293. Rorty describes the process through which he manipulates his students' sentiments

in such a way that they imagine themselves in the shoes of the despised and oppressed. Such students are already so nice that they are eager to define their identity in nonexclusionary terms. 
stories can generate the sympathy that Rorty argues is crucial to a human rights culture. ${ }^{294}$ As he suggests,

[A] better sort of answer [than philosophy] is the sort of long, sad, sentimental story which begins, "because this is what it is like to be in her situation - to be far from home, among strangers,' . . . such stories, repeated and varied over the centuries, have induced us, the safe, rich, powerful people, to tolerate, and even to cherish, powerless people-people whose appearance or habits or beliefs at first seemed an insult to our own moral identity, our sense of the limits of permissible human variation. 295

Finally, "incredulity toward metanarrative" resonates with Thomas Dewey's old-fashioned American pragmatism. ${ }^{296}$ As a skeptical response to specious abstractions, it can even be turned against certain claims of postmodernism itself. ${ }^{297}$ Even if we share the postmodern aversion to bureaucracy, for example, pragmatic skepticism requires us to distinguish between bureaucracy under Stalin ${ }^{298}$ and bureaucracy under Kofi

Producing generations of nice, tolerant, well-off, secure, otherrespecting students of this sort in all parts of the world is just what is needed-indeed all that is needed-to achieve an Enlightenment utopia.

Rorty, supra note 94, at 127. But see SCHLAG, supra note 191, at 20 (describing another option "for those scholars who have figured out what should be done-for example, we should all be really nice to each other. ....").

294. Rorty argues that resistance to "the human rights culture" is usually traceable to the deprivation

of two ... concrete things: security and sympathy. By "security" I mean conditions of life sufficiently risk free as to make one's difference from others inessential to one's self-respect, one's sense of worth . . . By "sympathy" I mean the sort of reaction that ... white Americans had more of after reading Uncle Tom's Cabin than before, the sort that we have more of after watching TV programs about the genocide in Bosnia.

Rorty, supra note 94, at 128 . The whole world is watching. See SASSEN, supra note 2 , at 92 (noting the "growing integration of communications media across the globe, which facilitates instantaneous reporting of violations").

295. Rorty, supra note 94 , at $133-34$.

296. See HUYSSEN, supra note 19, at 225 (noting Rorty's affinity with Dewey, and the tilt of postmodernism in general "toward various pragmatisms"). See also DE SOUSA SANTOS, supra note 14, at 135 (noting debt of critical sociology to twentieth century American pragmatism).

297. Activists such as Chandra Mohanty, for example, warn against a "constructed idealization of the Third World Woman." BRAIDOTTI ET AL., supra note 107, at 173. See also NuSSBAUM, supra note 63, at 35 (describing a French postmodernist who deplored the export of the smallpox vaccine to India because it made a small cult worshiping a particular goddess supposed to protect against smallpox obsolete).

298. John Gray, comparing the Enlightenment project with the former Soviet Union, argues that

what these Utopias have in common is more fundamental than their differences. In their cult of reason and efficiency, their ignorance of 
Annan. ${ }^{299}$ This Articles does not suggest that such skepticism should be used to short-circuit rigorous inquiry, but that it is useful in deflating a broad range of abstract systems.

\section{The Cultural Logic of Late Capitalism}

The metonym ${ }^{300}$ of an "International Superstore"301_in which laws, institutions, and norms are commodities-is useful for marginalized women for several reasons. First, the International Superstore is open to everyone; international law need not be some rarified discipline, reserved for an elite. Second, related but distinct, "open to everyone" does not mean that everyone enjoys equal access. Indeed, access to international law, like access to law in general, is determined in large part by market factors. The International Superstore metonym makes these questions of access, and their relationship to women's economic subordination, explicit. ${ }^{302}$ Third, precisely because the International Superstore promises nothing, ${ }^{303}$ it shifts agency from "History" or "God" to those who seek access themselves. ${ }^{304}$ The International Superstore merely offers tools. Fourth, while

history and their contempt for the ways of life they consign to poverty or extinction, they embody the same rationalist hubris and cultural imperialism that have marked the central traditions of Enlightenment thinking throughout its history.

GRAY, supra note 10 , at 3 .

299. As Professor Schlag observes, however,

[F]or postmodernism, the production of intellectual work that participates ... in the ideology of this individualist humanist self is at best normatively ambivalent. On the one hand, such work may help achieve some desirable concrete end; on the other, the very performance of such work reproduces precisely the form of thought, the very rhetoric by which bureaucratic institutional practices re-present, organize, and reproduce their own operations, their own performances as the choices of autonomous, rational agents.

SCHLAG, supra note 191, at 24-25.

300. See supra note 261 and accompanying text.

301. See supra notes $12-15$ and accompanying text.

302. Postmodernism offers no grand theory such as Marx's "withering away of the state" or contemporary "democracy," which either obviates the need for access or promises access, at least in theory.

303. This distinguishes it from classic international human rights law, which promises support for those denied their economic rights, but in fact promotes a free market ideology that often precludes such support. See supra Part III.A.2.b.i.

304. "The desperate hope for a noncontingent and powerful ally is, according to Nietzsche, the common core of Platonism, of religious insistence on divine omnipotence, and of Kantian moral philosophy." Rorty, supra note 94, at 130-31; see also Schlag, supra note 15. 
Professor Koskenemmi and others have criticized the pervasiveness of free market imagery, ${ }^{305}$ the use of market idiom suggests both the importance of spin and the possibility of creative appropriation. ${ }^{306}$ Finally, but critically, that which can be obtained in the International Superstore can be used for different purposes by different players. Thus, the fact that international law can and has been used to protect capital at the expense of poor women for a very long time $e^{\mathbf{3 0 7}}$ is neither an anomaly, an unfortunate historical accident safely in the past, nor an inevitability. ${ }^{308}$

\section{The Bottom Line}

A major problem with the proposition that "postmodernism may be useful for women dealing with globalization" is that postmodernism rejects the foundational metanarrative in which "useful for women" is a meaningful phrase. Rather, a postmodernist insists that what is useful only makes sense from a particular woman's perspective, in a particular context, at a particular time. Even-or especially-the blandest assertion demands interrogation. ${ }^{309}$ Thus, postmodernism threatens the whole project. The phrase, "women dealing with globalization," for example, enlarges experience to a meaningless scale. The Thai girl waiting for her next businessman is not "dealing with globalization;" she is hoping he will be quick. But what do such

305. See Koskenniemi, supra note 1, at 352 ("I had difficulty with the suggested shopping-mall approach to 'method,' the assumption that styles of legal writing are like brands of detergent that can be put on display . . . to be picked up by the customer in accordance with his/her idiosyncratic preferences.").

306. See infra Part IV.B.1. Another effective example of "benevolent subversion" would be the Jubilee 2000 initiative, which called for the cancellation of the unpayable debt of the world's poorest countries (17 million signatures were handed over to the G8 world leaders in Cologne on June 19, 1999). See Jubilee 2000 Coalition: A Debt-free Start for a Billion People (visited Apr. 11, 2000) <http://www.jubilee2000uk.org>. See also Bob Davis, G-7 Moves to Revamp Financial Systems, WALL ST. J., June 21, 1999, at A23; supra note 59 (describing the takeover of the McDonald's in Provence by French chicken farmers).

307. See, e.g., Barcelona Traction, Light \& Power Co. (Belg. v. Spain), 1970 I.C.J. 3, 246, 247 (Feb. 5).

308. See Sassen, supra note 4, at 31 (explaining that "because globalization is creating new operational and formal openings for the participation of non-State actors and subjects ... women and other non-State actors can gain more representation in international law; contribute to the making of international law; and give new meaning to older forms of international participation . . . .). See also Berman, supra note 281, at 1524 (explaining how we can "both . . . mourn legal history's horrors and . . . believe in law's ever-present emancipatory potential").

309. See, e.g., FRIEDMAN, supra note 40, at xiv (describing the era from the mid-1800s to the late 1920 s as a period of intense globalization). 
snapshots add up to? Is postmodernism irreconcilable with the metanarrative of human rights law? ${ }^{310}$

As Roy Boyne and Ali Rattansi observe, "[t]here is . . . a postmodernism of 'resistance' as well as a postmodernism of 'reaction." 311 Rorty, for example, explicitly adopts the vision of an Enlightenment Utopia. ${ }^{312}$ Martha Nussbaum takes a pragmatic approach: "[G]etting rid of transcendent standards does not mean getting rid of good reasons . . . ${ }^{n 13}$ Here, getting rid of transcendent human rights standards doesn't mean getting rid of the good reasons for assuring the mother in Moscow an alternative to begging in the subway. ${ }^{314}$

While some postmodernists relentlessly challenge normativity, ${ }^{315}$ others concede that the process of questioning, trashing, deconstructing, "always [must] stop." 316 Postmodernists

310. See Enrique R. Carrasco, Opposition, Justice, Structuralism, and Particularity: Intersections Between LatCrit Theory and Law and Development Studies, 28 U. MIAMI INTER-AM. L. REV. 313, 318 (1996-97) (proposing "a hopeful quest for enlightenment leading eventually to liberation while at the same time rejecting modernism's epistemological foundations").

311. Roy Boyne \& Ali Rattansi, The Theory and Politics of Postmodernism: By Way of an Introduction, in POSTMODERNISM AND SOCIETY 1, 29 (Roy Boyne \& Ali Rattansi eds., 1990).

Postmodernism ... operates in a field of tension between tradition and innovation, conservation and renewal ... in which the second terms are no longer automatically privileged over the first; a field of tension which can no longer be grasped in categories such as progress vs. reaction, Left vs. Right .... The fact that such dichotomies, which after all are central to the classical account of modernism, have broken down is part of the shift.

HUYSSEN, supra note 19, at 220.

312. See Rorty, supra note 94, at 118. See also FALK, supra note 14 , at 1 (endorsing "rooted utopianism"). Cf. Huyssen, who states:

Habermas defends modernity, conceived as an unfinished nisus of emancipation-that is, once again, discounting its dark and savage sideagainst the "reactions" of postmodern culture .... [asking] "Should we try to hold onto the intentions of the Enlightenment, feeble as they may be, or should we declare the entire project of modernity a lost cause?

HUYSSEN, supra note 19, at 223.

313. Martha C. Nussbaum, Valuing Values: A Case for Reasoned Commitment, 6 YAlE J. L. \& HUMAN. 197, 202 (1994).

314. It does require a specific inquiry, however, and, at the same time, a deep suspicion of delegating authority for that inquiry to a bureaucracy which cannot be held accountable.

315. See generally SCHLAG, supra note 15. Those most committed to the "pure" intellectual project of postmodernism, ironically, seem to be those privileged subjects of the Enlightenment, Western white males.

316. J. M. Balkin, Tradition, Betrayal, and the Politics of Deconstruction, 11 CARDozo L. REv. 1613, 1627 (1990). This is not, of course, the same as closure. Some of us stop sooner than others because in some contexts some of us have 
can and do support human rights, but they make the linkage between rights and concrete experience explicit and direct, insisting on contingency and ongoing interrogation. Thus, while postmodernism does not preclude a bottom line, it insists on bottom lines that are unstable and that may vary from place to place and over time $\mathbf{3}^{317}$ to reflect shifting consensus and ongoing dialogue. ${ }^{318}$

\section{B. The Roles of Women}

"Let the new faces play what tricks they will ..."

-W. B. Yeats, The New Faces 319

\section{Fragmentation and Discontinuity: Women as Subversives}

Women everywhere are part of that vociferous constituency Virginia Leary has described as "clamoring at the gates"320 of the

less choice. See, e.g., Catherine McKinnon, Theory is Not a Luxury, in RECONCEIVING REALITY, supra note 233 (arguing that postmodern "indeterminacy" is irrelevant to rape victims in Bosnia). In the context of economic rights, the bottom line of human needs may suggest a common sense stopping point. For an ambitious effort to delineate the parameters of "central human functional capabilities," see NUSSBAUM, supra note 63, at 41-42.

317. See Barbara Stark, Bottom Line Feminist Theory: The Dream of a Common Language, 23 HARV. WOMEN's L.J. 227 (2000). Cf. Koskenniemi, supra note 1, at 356. ("The final arbiter of what works is nothing other than the context (academic or professional) in which one argues.")

318. See Otto, supra note 183, at 5 (arguing for "universality understood as dialogue, in the sense of struggle, rather than as a disciplinary civilizing mission of Europe").

319. VARIORUM EDITION, supra note 1, at 435. See JOHN UNTERECKER, A READER's GuIDE TO WILLIAM BUTLER YEATS 15-18 (1971) (explaining Yeats's "doctrine of the Mask," in which "reality [was] neither to be found in that buried self which directs . . . a man's life or in its Mask, the anti-self, but in the product born of their struggle $)^{\eta}$. See also RICHARD ELLMANN, YEATS: THE MAN AND THE MASKS (1948).

320. Virginia Leary, Lecture at the Annual Meeting of the ASIL (Mar. 25, 1999). See also Joseph Kahn \& David E. Sanger, Impasse on Trade Delivers a Stinging Blow to Clinton, N.Y. TIMES, Dec. 5, 1999, at 1 (describing how protesters, along with the lack of consensus among states, blocked efforts to liberalize trade and broaden mandate of the WTO). But see Fareed Zakaria, After the Storm Passes, NewsweEk, Dec. 13, 1999, at 40 (characterizing the protests as "the carnival tactics of a small but effective minority") Cf. HUYSSEN, supra note 19, at 47:

But when the 19th and early 20th centuries conjured up the threat of the masses "rattling at the gate," to quote Hall, and lamented the concomitant decline of culture and civilization,... there was yet another hidden subject. In the age of nascent socialism and the first major woman's 
WTO, outraged by its neglect of their human rights. From a classic perspective, the cacophony at the gates precludes a coherent systemic response. From a postmodern perspective, this is not necessarily bad. Rather, it deters the conflation of disparate, even conflicting, claims. It requires that each distinct claim be heard and supports fragmentary, discontinuous, subversions. As Huyssen explains:

We are witnessing . . . a massive 'delegitimization' of the master codes in society, a desuetude of the metanarratives ... the most baleful example [of subversion] is the rampant terrorism of our time. But 'subversion' may take other, more benevolent, forms such as minority movements or the feminization of culture, which also requires decanonization. ${ }^{321}$

Women can exploit economic rights law to further such benevolent forms of subversion, and thus further their respective claims in different ways in different contexts. ${ }^{322}$ On a national level, for example, women in Russia can use the Economic Covenant to embarrass their leaders and to demand at least a partial re-weaving of social safety nets. ${ }^{323}$ On the international, as well as on the national level, ${ }^{324}$ women can join any of the innumerable Nongovernmental Organizations (NGOs) ${ }^{325}$ that have

movement in Europe, the masses knocking at the gate were also women, knocking at the gate of a male-dominated culture.

Id.

321. HUYSSEN, supra note 19, at 169. For a description of the "new social movements" emerging in the 1970's "renouncing violence and shifting expectations for renewal and reform away from the political center," see FALK, supra note 14 , at 20 .

322. See, e.g., Steiner, supra note 190, at 10 (asking "what techniques and pressures are available to international organizations, national governments and nongovernmental organizations to secure" compliance); Dau-Schmidt, supra note 7 , at 58 (urging "feminists [to] seek solutions to women's problems not only on the local and national levels, but on the international level as well").

323. As the new Director of the ILO has recently noted, "A central reality of the global economy is that a majority of people don't have basic social protections of any kind." Steven Greenhouse, Making Markets Work for All, N.Y. TIMES, Oct. 24, 1999, § 3, at 4. As Professor Charlesworth notes, "[c]laims based on international law can carry an emotional and moral legitimacy that can have considerable political force." Charlesworth, supra note 94 , at 393 .

324. For a thoughtful overview, see STEINER \& ALSTON, supra note 93, at 457-99.

325. For an excellent overview, see Michael Posner, Foreword: Human Rights and Nongovernmental Organizations on the Eve of the Next Century, 66 FORDHAM L. REV. 627 (1997) (describing the growth of NGOs since the 1960s, and noting the pivotal role of Amnesty International). See also Afra Afsharipour, Note, Empowering Ourselves: The Role of Women's NGOs in the Enforcement of the Women's Convention, 99 CoLUM. L. REV. 129 (1999); Schachter, supra note 64, at 13 (citing women's NGOs as a "prime example" of a new force for political change in the international sphere). 
sprung up to challenge national governments, IOs, and MNCs. ${ }^{326}$

A few of the Major Players are receptive. The World Bank now holds yearly meetings with the External Gender Consultative Group. ${ }^{327}$ ECOSOC has extended consultative status to international NGOs which meet certain standards ${ }^{328}$ and the Committee on Economic and Social Rights (CESCR) has already opened its doors to NGOs. ${ }^{329}$ As the delegates at the Fifth Annual NGO Forum on World Bank and IMF Lending concluded, however, NGO "coalitions have succeeded only when efforts to pressure the Bank by 'working within the system'... have been accompanied by the mobilization of popular movements;"330 that is, the mechanisms of human rights law may well be useful, but only as part of a broader political effort.

\section{Incredulity Toward Metanarratives: Women as Storytellers}

As noted above, ${ }^{331}$ the importance of storytelling is increasingly recognized, especially for the marginalized. First,

326. See, e.g., BRADIOTTI ET AL., supra note 107, at 81 (discussing the Development with Women for a New Era (DAWN), a group of Southern women whose empowerment approach "has not been very popular with many governments and aid agencies because of its potential for challenging both local and global patriarchal power structures"). See generally NGOS, THE UN AND Global GOVERNANCE (Thomas G. Weiss \& Leon Gordenker, eds. 1996).

327. See Lydia Williams, Oxfam Honored by Peers for Gender Equity Work, OXFAM AM. VIEWPOINT, Fall 1998, at 12-13.

328. See Report on the Review of Arrangements for Consultation with Nongovernmental Organizations, U.N. Doc. A/49/215 (1994) at 12 (reprinted in STEINER \& ALSTON, supra note 31, at 493-94). See, e.g., Consultative Relationship Between the United Nations and Non-governmental Organizations, E.S.C. Res. 1996/31 (affirming consultative status provisions). See also Dinah Shelton, The Participation of Nongovernmental Organizations in International Judicial Proceedings, 88 AM. J. INT'L L. 611 (1994); Diane Otto, Nongovernmental Organizations in the United Nations System: The Emerging Role of International Civil Society, 18 Hum. RTS. Q. 107 (1996). But see Peter J. Spiro, New Global Potenates: Nongovernmental Organizations in the "Unregulated" Marketplace, 18 CARDOzo L. REV. 957 (1996) (discussing the lack of accountability of NGOs).

329. As I have noted elsewhere, the CESCR is already postmodern. See Stark, The Other Half of the International Bill of Rights, supra note 233. See also HUYSSEN, supra note 19, at 167 ("They have been speaking postmodernism all their lives without knowing it."); Afsharipour, supra note 325, at 157 (describing how women's NGOs increased their access to the U.N. system).

330. MCAFEE, supra note 44 , at 223. For a compelling case study, supporting a similar conclusion, see David A. Wirth, Legitimacy, Accountability and Partnership: A Model for Advocacy on Third World Environmental Issues, 100 YALE L. J. 2645 (1991) (describing how concerned groups prevented the World Bank from approving a forestry project in Sri Lanka without conducting an environmental impact study). See generally WORLD BANK, HOW THE WORLD BANK WORKS WITH NON-GOVERNMENTAL ORGANIZATIONS (1990).

331. See supra Part II.B.2. 
stories can generate the sympathy that Rorty argues is necessary for human rights culture. ${ }^{\mathbf{3} 2}$ Second, they can be used to identify and organize political groups, as Schlag suggests. ${ }^{333}$ Ofelia's story, for example, came out of a series of ad hoc exchanges between a group of displaced U.S. workers and the maquiladora workers who took their jobs. ${ }^{334}$ Finally, stories can be used as a "motivational orientation" to shame listeners into action.335 Stories like those about the sweatshops involved in the production of WalMart's Kathie Lee Gifford clothing line, for example, prompted a public outcry. ${ }^{336}$

\section{The Cultural Logic of Late Capitalism: Women as Workers/Consumers/Investors}

Women workers can no longer rely on international unions or the ILO to assure them decent working conditions, benefits or wages, if indeed they ever could. ${ }^{337}$ The premises of industrial labor law are increasingly irrelevant as law to most of the world's women, including the growing numbers in the informal sector. ${ }^{338}$ The norms to which such laws have contributed, on the other hand, may well be useful. American readers are likely to wince, for example, at the prospect of a sixteen-year old working fortyfour hours per week in a factory. ${ }^{339}$ At the same time, a

332. See supra notes $269-70$ and accompanying text.

333. See Schlag, supra note 15, at 228. See also Lucie Evelyn White, "Democracy" in Development Practice: Essays On a Fugitive Theme, 64 TENN. L. REv. 1073, 1081-83 (1997) (describing how a group of low-income women, encouraged to form a loosely knit consciousness-raising group, gradually undertook outings and eventually decided to collaborate on a quilt together).

334. See Frances Lee Ansley, U.S.-Mexico Free Trade From the Bottom: A Postcard From the Border, 1 TEx. J. WOMEN \& L. 193, 199-200 (1992) (describing plays in English and Spanish which the women put on for each other).

335. See Schlag, supra note 15, at 227.

336. See Stephanie Strom, A Sweetheart Becomes Suspect: Looking Behind Those Kathie Lee Labels, N.Y. TrMES, June 27, 1996 at D1. See also Chen, supra note 72, at 39 (telling the story of women in Bangladesh who "broke with tradition to join the work force" to show "how local traditions and local policies can evolve and change.")

337. See International Labor Organization, Human Rights, <http://www.ilo.org/public/english>. But see Greenhouse, supra note 323, at 4 (Juan Somabia, the new Director of the ILO, promises to change the organization's reputation as a "lethargic bureaucracy.").

338. For a thought-provoking collection of essays, see HUMAN RIGHTS, LABOR RightS, and International Trade (Lance A. Compa \& Stephen F. Diamond eds., 1996).

339. See supra Part II.B.2.a. See generally ANNETTE FuENTES \& BARBARA EHRENREICH, WOMEN IN THE GLOBAL FACTORY (1983) (explaining how Third World women, in part encouraged by IMF and World Bank policies, left rural areas to become the new industrial workforce). 
postmodernist would question the orthodoxy of a forty-hour week at a "family wage."340 How many hours per week do other Mexicans work? Is a family wage, with its presumption of a stayat-home mother, good for women?

Women also have tremendous potential leverage as consumers and investors, despite their poverty. Even the poorest women in the poorest countries can exercise some leverage as consumers because, as Debora Spar points out, non-apparel MNCs are "in the end" looking for local markets. ${ }^{341}$

Since buying food and other necessities for their families is typically part of women's unpaid work, women can support "social labeling" and the businesses that support women as workers. ${ }^{342}$

Women in the industrialized world obviously have even more leverage as consumers. In response to such leverage, over 100 U.S. companies, including Reebok, Sears, Levi-Strauss, Gap and Home Depot, have adopted codes of conduct to assure consumers that their business practices are consistent with human rights. ${ }^{343}$ Women also have substantial leverage as investors, especially in view of the increasing independence of the pension funds in which they participate. ${ }^{344}$ Investors like Mary Jo Paoni, the Midwestern secretary quoted above, ${ }^{345}$ affect global investment

340. "Poverty is no excuse for slavery. On the other hand, there are labor standards, for example, rules for minimum wage or maximum hours. Those matters do vary with the country's level of development." Globalization, Development and Human Rights: Clarifying the Terms of the Debate, in BusINEss AND HUMAN RIGHTS, supra note 20 at 15 . For a discussion of the efforts by the ILO and others to develop flexible standards that at the same time discourage exploitation, see Sarah H. Cleveland, Global Labor Rights and the Alien Tort Claims Act (Book Review), 76 TEx. L. REV. 1533, 1558-59 (1998).

341. BUSINESS AND HUMAN RIGHTS, supra note 20, at $30-31$ (remarks of Debora Spar). The creation of such local markets may itself have disturbing consequences. See, e.g., Kristof, supra note 158 (describing girl who was sold by her parents for a karaoke system).

342. See Steiner, supra note 190, at 12 (explaining how, if producers or distributors cooperate, "social labeling" of products can inform "consumers whether, for example, child labor was used in their manufacture."). Sarah Cleveland describes the German-sponsored Rugmark project, in which exporters in India and Nepal can mark their carpets as child-labor free. See Cleveland, supra note 340 , at 1553 n.97.

343. See Cleveland, supra note 340 , at 1551 . But see supra text notes 22426 and accompanying text (effectiveness of such codes is an open question). Because codes of conduct are a public relations tool, however, they can trigger the "mobilization of shame," surely one of the most useful tactics of human rights advocacy.

344. See Carter, supra note 227 (discussing the increasing importance of independent capital).

345. See supra notes 229-30 and accompanying text. 
and, given an explicit choice, are unlikely to maximize profits at the expense of human rights. ${ }^{346}$

\section{The Roles of Lawyers}

\section{Practice}

a. Access to the Superstore

Under the classic conception, the lawyer's job is to translate the client's story into a legal claim. Under the postmodern conception, in contrast, the lawyer's job is to provide a space in which the client can tell her story. ${ }^{347}$ This provides wider scope for lawyers, but it distances them from the reassuring authority of the familiar legal machinery. While legal expertise remains important, it no longer wags the dog.

Since the objective is to provide marginalized women with access to the Superstore, lawyers' roles are open-ended. In Senegal, for example, the Association for Women and Alternative Communication is launching a women's radio station to educate women about their legal rights and similar matters. ${ }^{348}$ In the ASIL radio series on The Individual and Globalization, lawyers helped create a space in which women in the developing world told their stories to a broad audience. ${ }^{349}$ In Ecuador, a lawyer skilled in mediation enables an indigenous group to avoid the expense of national courts. ${ }^{350}$ Postmodern lawyers can even appropriate advertising. Pierre Schlag describes a Mobil advertisement, for example, in which the oil company exploits

346. Gender polls indicate that women, like Rorty's students, supra note 280, are responsive to such concerns. See, e.g., Investing in Change: Shareholder Resolutions Add a New Tool to AIUSA's Activist Kit, AMNESTY ACTION, Fall 1999, at 5 (noting that Amnesty International has purchased stock in Chevron, Mobil, and Exxon "for the purpose of filing shareholder resolutions . . . As a shareholder, AIUSA will have direct contact with top management in these companies, increasing our ability to engage in constructive dialogue. ${ }^{m}$ ).

347. For an illuminating example, see Lucie E. White, Subordination, Rhetorical Survival Skills, and Sunday Shoes: Notes on the Hearing of Mrs. G., 38 BUFF. L. REV. 1, 31-32 (1990) (describing how White's client, Mrs. G., abandons her carefully prepared script at a hearing and prevails on her own terms).

348. Launching Women's Radio Station in Senegal, OXFAM AM. VIEWPOINT, Fall 1998, at 4 . Since $75 \%$ of adult women are illiterate, radio is a particularly important medium.

349. See WILIG NEWSL, Fall 1999 at 2.

350. See Laura Roper, Revitalizing the Indigenous Movement in Ecuador, OXFAM AM. VIEWPOINT, Fall 1998, at 6-7. Mediation is a staple in the International Superstore. See, e.g., ROGER FISHER ET AL., GETTING TO YES: NEgOTIATING AGREEMENT WITHOUT GIVING IN (1991). 
refugees to enhance its corporate image. ${ }^{351}$ Whatever its objective, the advertisement may well contribute to Rorty's "sympathy"352_unfocused, sentimental, but sympathy nevertheless. ${ }^{353}$

\section{b. Representing Clients}

The postmodern attorney represents her client in a new way. Unlike the classic lawyer, she does not seek to simply represent her client's interests before the appropriate tribunal. Rather, she recognizes that those interests may not be cognizable under the law. The economic rights of marginalized women are rarely recognized in national law and only vaguely suggested in international law. ${ }^{354}$ The postmodern attorney must find other ways to support her clients.

A Campaign for Economic Justice, for example, was organized by women who had been on welfare themselves. They filled a bus and traveled across the country for two months, stopping for a series of carefully orchestrated meetings, rallies, and slide shows. They concluded their campaign at the United Nations, where they presented a petition demanding recognition of their economic rights. ${ }^{355}$ They needed lawyers for such simple things as permits and access to audiences. Yale law students provided both during a 1998 Conference on Critical Race Theory. 356

\section{Deconstructing Theory}

Unlike classic legal theorists, whose task is to contribute to human rights law, to articulate clear standards, and to buttress

351. See Schlag, supra note 15, at 226. Schlag condemns this as "the appropriation of moral and political value signs for ends of self-promotion. ${ }^{\text {Id. }}$. at 227.

352. See supra note 294 and accompanying text.

353. It may be especially useful, in fact, when its motivation is exposed, as Professor Schlag does in his article. See Schlag, supra note 15, at 226.

354. See supra Part III.A.2.a.

355. Others have launched similar efforts. See, e.g., March of the Americas for Economic Human Rights <http://www. libertynet.org/kwru/> (visited April 20, $2000)$.

356. Critical Race THeory Conference, Nov. 1998, Yale Law School. Other media, such as films on which lawyers serve as consultants, may also enable clients to reach a broader audience. See, e.g., From tHE MOUNTANS TO THE Maquiladoras (Highlander 1993). As Professor Schachter notes, "we must face the sobering thought that the needs of distant strangers are not high on the lists of national interests." Schachter, supra note 64, at 19; see also Chomsky, supra note 60 (describing the role of grassroots groups in the defeat of the MAI). 
the human rights system, ${ }^{357}$ postmodern legal theorists interrogate that system and deconstruct ${ }^{358}$ and expose the ways in which it, too, reifies power. International "crits," feminists, Latcrit, and critical race scholars have all begun this work.

Critical legal scholars such as David Kennedy ${ }^{359}$ and Professor Koskenniemi ${ }^{360}$ have shown how international law reinforces existing power structures. Feminists have shown how these power structures are gendered. As Christine Chinkin, ${ }^{361}$ Hillary Charlesworth, ${ }^{362}$ Shelley Wright, ${ }^{363}$ Diane Otto, ${ }^{364}$ Hope Lewis, ${ }^{365}$ Isabelle Gunning, ${ }^{366}$ and others have demonstrated, international law recapitulates and reinforces the public/private distinction, designating the public world of law and state as "male"367 and relegating women to the private, hidden world of custom and the family. ${ }^{368}$ Karen Engel has further

357. See supra Part III.B.

358. See POST-Modern LaW: EnLightenment, REvolution and the Death of MAN at vii (Anthony Carty ed., 1990) (describing "post-modernism as a method of legal deconstruction"). But see Dennis Patterson, POSTMODERNISM/FEMINISM/LAW, 77 CORNELL L. REv. 254, 313 n.276 (1992) ("Derrida is not postmodern. Because deconstruction further atomizes the individual into discursive fragments, it represents the modernist spirit at its most excessive."(citations omitted)); $c f$. Koskenniemi, supra note 1, at $\mathbf{3 6 0}$ ('But 'deconstruction,' too, is only a cultural or historical convention, a style with an emancipatory potential but which-just like Kantian universalism-is always in danger of being transformed into a means of status quo legitimation."). For present purposes, deconstruction may be understood as a method of critical analysis while postmodernism may be seen as a wide-ranging critique of modernity. Deconstruction may contribute to this critique, which may also be deconstructed.

359. See DAVID KENNEDY, INTERNATIONAL LEGAL STRUCTURES (1987).

360. See MARTTI KOSKENNIEMI, FROM APOLOGY TO UTOPIA: THE STRUCTURE OF INTERNATIONAL LEGAL ARGUMENT (1989).

361. See Christine Chinkin, A Gendered Perspective to the International Use of Force, 12 AUSTL. Y.B. INT'L L. 279 (1992).

362. '[I]deas about femininity' and 'masculinity' are incorporated into international legal rules and structures, silencing women's voices and reinforcing the globally observed domination of women by men." Charlesworth, supra note 94 , at 392.

363. See Shelly Wright, Economic Rights and Social Justice: A Feminist Analysis of Some International Human Rights Conventions, 12 AUSTL. Y.B. INT'L L. 241 (1992).

364. See Otto, supra note 183.

365. See, e.g., Lewis, supra note 157; Lewis, supra note 257.

366. See Gunning, supra note 257.

367. Cf. HUYSSEN, supra note 19 at 45 (describing French society of Flaubert's time as one in which "masculinity is identified with action, enterprise, and progress-with the realms of business, industry, science, and law").

368. "International legal discourse rests on a series of distinctions; for example, objective/subjective, legal/political, logic/emotion, order/anarchy, mind/body .... . Feminist scholars have drawn attention to the gendered coding of these binary oppositions-the first term signifying 'male' characteristics and the second 'female." ${ }^{m}$ Charlesworth, supra note 94, at 382. Bina Agarwal, similarly, urges women to "deconstruct the power structure that sustains a specific 
deconstructed the public/private distinction, showing that "private" is not necessarily the subordinated conception. ${ }^{369}$ Critical race and Latcrit scholars, such as Ruth Gordon, 370 Professor Lewis, ${ }^{371}$ Henry Richardson III, ${ }^{372}$ Adrien Wing, Berta Esperanza Truyol-Hernandez, ${ }^{373}$ and Professor Iglesias ${ }^{374}$ have shown how power structures are raced and the ways in which international law is "white" and Western, from the laws of discovery to the laws governing bilateral investment treaties. ${ }^{375}$ Sometimes this leads to suggestions for programmatic reforms. But often, and often at its best, it does not. ${ }^{376}$

This is not to suggest, of course, that all of these theorists are postmodern. When they argue that the law should be less raced, or less gendered, or how it can better incorporate the interests of the subordinated, they are well within classic discourse. ${ }^{377}$ When

patriarchal ideology which has assigned women a closer relationship to nature ...."BRAIDOTTI ET AL., supra note 107, at 172 .

369. Karen Engel, After the Collapse of the Public/Private Distinction: Strategizing Women's Rights, in RECONCEIVING REALITY, supra note 233, at 143.

370. See, e.g., Ruth E. Gordon, Some Legal Problems with Trusteeship, 28 CoRnEll INT'L L.J. 301 (1995); Ruth Gordon, Saving Failed States: Sometimes a Neocolonialist Notion, 12 AM. U. J. INT'L L. \& POL'Y 909 (1997).

371. See generally Lewis, supra note 157; Lewis, supra note 257.

372. See generally Henry J. Richardson III, "Failed States," SelfDetermination, and Preventive Diplomacy: Colonialist Nostalgia and Democratic Expectations, 10 TEMP. INT'L \& COMP. L.J. 1 (1996) (examining international law's role in regards to the plight of "failed states").

373. Berta Esperanza Hernández-Truyol, Borders (En)Gendered: Normativities, Latinas, and a Latcrit Paradigm, 72 N.Y.U. L. REV. 882, $892-911$ (1997) (examining the similarities and differences between Latina/o normativities and non-Latina/o normativities).

374. Iglesias, supra note 193, at 182 (arguing that international law topics "take on new dimensions when approached through a LatCrit perspective").

375. The private bar has also joined the discussion. See, e.g., Anthony D. Taibi, Racial Justice in the Age of the Global Economy: Community Empowerment and Global Strategy, 44 DuKE L.J. 928, 958-64 (1995) (arguing that the "dominant institutions ... represent the culture of dead White European males").

376. Indeed, as Pierre Schlag has argued, such analysis may be most useful in exposing the limits of analysis that aim at action:

"What should we do?" is an interruption. It is an interruption posing as an origin. It poses as an origin in that it takes itself to be the original motivation for engaging in legal thought. And yet here ... [it] interrupts the process of trying to understand what enterprise we, as legal thinkers, are already engaged in.

SCHLAG, supra note 191 , at 27.

377. See, e.g., Barbara Stark, Critical Race Theory and International Human Rights: Walking Our Boundaries, in CRITICAL RACE THEORY ANTHOLOGY (1999) (arguing that ratification of the Economic Covenant is in the interests of AfricanAmericans); Barbara Stark, International Human Rights, Feminist Jurisprudence and Nietzsche's "Eternal Return": Turning the Wheel, 19 HARV. WOMEN's L.J. 169, 
they argue, however, that even the most well-intentioned reforms replicate the hierarchies of privilege and subordination that infuse the deep structure of the law, they are more postmodern. This is obviously not a bright line, ${ }^{\mathbf{3 7 8}}$ and the boundaries are more fluid in international law than in domestic law. ${ }^{379}$ Nevertheless, these scholars are closer to postmodernism than, for example, the "new legal process" 380 because they are all challenging the boundaries of law itself. ${ }^{381}$

\section{A PARADOX?}

\section{A. From a Classic Perspective}

Basic notions, such as "useful" and "forward-looking," are themselves part of the classic conception, problematic "sites of contestation" in postmodernism rather than agreed-upon objectives. ${ }^{382}$ Indeed, a postmodernist questions the extent to which human rights themselves are good for women. ${ }^{383}$ She may even challenge the notion of "women" as a category. 384 Thus, from a classic perspective, postmodernism may be intellectually

178-80 (1996) [hereinafter Stark, Turning the Wheel] (arguing that ratification of the Economic Covenant is in the interests of U.S. women).

378. See generally COSTAS DOUZINAS ET AL., POSTMODERN JURISPRUDENCE: THE LAW OF TEXT IN THE TEXTS OF LAW 28 (1991) ("Jurisprudence goes postmodern in order to retain and withdraw its old commitment to plural and open forms of reason(s) and communities.").

379. See, e.g., Louis Henkin, InTERnational LaW: Politics, VAlues and FUNCTIONS (1995)

380. Mary Ellen O'Connell, New International Legal Process, 93 AM. J. INT'L L. 334, 345-49 (1999) (describing how international legal rules are actually used by the makers of foreign policy).

381. See HuYSSEN, supra note 19, at 56 (noting the relationship between "the ecological and environmental critique of industrial and post-industrial capitalism" and the "feminist critique of bourgeois patriarchy").

382. As Feldman notes, "the term 'postmodern tool' is oxymoronic. That is, the focus on the use of tools is more of a modernistic concept than a postmodernist one." Feldman, supra note 289, at 160 n.33.

383. See, e.g., Engel, supra note 233, at 143.

384. See Judith ButLer, Gender TROUBLE: Feminism AND the SUBVERSion of IDENTITY 140-41 (1990). But see Susan H. Williams, Globalization, Privitization, and $a$ Feminist Public, 4 IND. J. GLOB. LEGAL STUD. 97, which argues that

feminism is not a preexisting set of principles to which newcomers must subscribe in order to join. It is, instead, a community of women searching together, through participatory and respectfully democratic mechanisms, for a shared vision of a good social life .... What women in one part of the world believe is a good life may be different from what women in other places believe....

Id. at 105. 
provocative, but it is hardly useful for those seeking to "make the world a better place for women." 385

The notion that the Major Players may be more effectively dealt with by a variety of ad hoc strategies, rather than by an approach structured by international human rights law, is similarly dubious from a classic perspective. Because the Major Players control such vast flows of capital, they must be subject to international institutions that can hold them accountable in a rigorous, systematic manner. Indeed, international institutions are the only ones capable of compiling the data to accurately assess the impact of globalization on women ${ }^{386}$ and of taking women's work into account in a comprehensive, meaningful way. ${ }^{387}$

The paradox here-that postmodern international law may be more useful and forward-looking than classic international lawcan be traced, first, to the anomalous position of human rights in classic international $\mathrm{law}^{388}$ and to the profoundly gendered structure of that law, 389 and, second, to the ways in which such anomalies and structural flaws are hidden, or repressed, in the classic conception and exposed in the postmodern conception. Both of these problems have been examined in depth by classic scholars, who have suggested measures to strengthen human rights law in general, and women's human rights law in particular, and how to use the insights of postmodernism to further human rights. ${ }^{390}$ While such measures are necessarily partial and incremental, they demonstrate the enduring capacity of classic international law to expand, change, and further human good.

In sum, the Major Players must be subject to "universal international law," for many of the same reasons that Professor Jonathan Charney has argued the environment must be subject to such law. ${ }^{391}$ The failure to date of the international system to

385. Regenia Gagnier, Feminist Postmodernism: The End of Feminism or the Ends of Theory?, in THeORETICAL PERSPECTIVES ON SEXUAl DifFERENCE 21, 21-24 (Deborah L. Rhode ed., 1990). As Gagnier continues, "On this point feminists agree, although many of us would extend the emancipatory project beyond women." Id. at 24.

386. See supra Part II.B.1.b.iii.

387. See supra Part II.B.1.b.ii

388. See HENKIN ET AL., supra note 232, at 295 (noting that "[u]nlike international law generally, ... human rights did not begin with a deeply-rooted basis in customary law.").

389. See supra notes 39-46 and accompanying authorities.

390. See generally Stark, Turning the Wheel, supra note 377; Otto, supra note 183 , at $36-44$.

391. Jonathan I. Charney, Universal International Law, 87 AM. J. INT'L L. 529, 529 (1993) (explaining that "unless all states are bound, an exempted recalcitrant state could act as a spoiler for the entire international community"). 
develop such law may be instructive, but that does not mean that efforts to do so should be abandoned.

\section{B. From a Postmodern Perspective: The Politics of Paradox}

The notion of paradox assumes an order, a particular logic, that postmodernism exposes as self-referential and arbitrary. Thus, from a postmodern perspective, an effort to generate a more universal economic rights law is misguided. Indeed, such efforts distract us from recognizing that the dearth of such law reflects the underlying "will to power" of the existing system. ${ }^{392}$ Rather, efforts should be diffuse, challenging existing parameters on multiple fronts, to make the Major Players accountable not to some yet-to-be-determined agency or law, but to specific, concrete constituencies whose human rights are violated by their actions. ${ }^{393}$

From a postmodernist perspective, similarly, data compilation may not be a priority for marginalized women, especially since such compilations have historically failed to take women's work into account in a meaningful way. Data may be particularly problematic in connection with the informal sector. Efforts to measure women's well-being are also problematic. At the very least, as Sen has shown, ${ }^{394}$ measurements must take factors such as access to education and health care into account, as well as income indicators. Indeed, the postmodernist may ask whether that which many women value most-love, the wellbeing of their families-is even quantifiable. Perhaps the most useful data for marginalized women are Sen's calculations of "missing women," 395 which measure absence. In short, as Santos and others have argued, we should rethink our relationship to data before we worry about "compiling" more of it." 396

Postmodern international law, accordingly, becomes the theory of choice for the disenfranchised and the neglectedconstituencies that everywhere are disproportionately female. Rather than assuming that the growth of human rights machinery or body of law is in itself "good," postmodern international law recognizes ever-shifting sites of ongoing political

392. See ScHLAG, supra note 191, at 27 (describing the limits of normative analysis).

393. The Major Players are already accountable to other constituencies, of course, such as investors (financial institutions), shareholders (MNCs), and States (IOs).

394. See supra note 95-96 and accompanying text.

395. See supra notes $92-94$ and accompanying text (estimating the number of "missing women" at "more than 100 million").

396. DE SOUSA SANTOS, supra note 23, at 103. 
struggle, always demanding, "Good for whom?" And, "who is being forgotten?,"397 always reminding us that while human rights norms, and company logos, may be the same in Moscow and Thailand, the answers to these crucial questions may well be different. Thus, from a postmodern perspective, the paradox simply reflects the ways in which postmodernism can be used to resist co-optation and to expose and privilege subordinated conceptions. 398

\section{CONCLUSION}

O may she live like some green laurel

Rooted in one dear perpetual place.

$$
\star \star \star *
$$

How but in custom and in ceremony

Are innocence and beauty born?

Ceremony's a name for the rich horn,

And custom for the spreading laurel tree.

$$
\text { -W. B. Yeats, A Prayer for my Daughter } 399
$$

Yeats' prayer for his daughter is not what I would pray for mine, but it resonates and it may well resonate most for the most marginalized women. The world he seeks for his daughter is a safe and peaceful one, in which her "self-delighting" soul will flourish. 400 His focus on a particular child in a particular place and his insistence on the crucial importance of human love, ${ }^{401}$

397. But see UnIVERSAL ABANDON? THE POLITICS OF POSTMODERnisM at xiv (Andrew Ross ed., 1988) (asking, "In whose interests is it, exactly, to declare the abandonment of universals?") (emphasis in original). As Seyla Benhabib has pointed out,

It is likely that we will have to live with this polytheism and dazzling "play of surfaces," ... for some time to come. Nor is it unwelcome that the frozen fronts of philosophy are becoming fluid again. Only it is necessary that we think the epistemic alternatives created by the present also to their moral and political ends. For questions of truth . . . are still matters of justice as well.

Seyla Benhabib, Epistemologies of Postmodernism: A Rejoinder to Jean-François Lyotard, in FEMINISM/ POSTMODERNISM 107, 124 (Linda J. Nicholson ed., 1990).

398. As noted above, one way in which postmodernists do so is through deconstruction. See supra Part IV.C.2.

399. VARIORUM EDITION, supra note 1, at 405-06.

400. A Prayer for my Daughter, supra note 1, at 405 . At least one critic has argued that the "Unity of Being" that Yeats "sought for the nation is close to what he sought for his daughter. He looked for the external identity of Ireland in her internal myth and folklore." KiINE, supra note 98, at 98.

401. As Yeats observes in A Prayer for My Son, children must depend on adults "Protecting, till the danger past/ With human love." A Prayer for my Son, in VARIORUM EDITION, supra note 1, at 435, 436. As Rorty notes, "The relevant similarities are not a matter of sharing a deep true self which instantiates true 
relationship, and connectedness evoke some of the deepest values that Friedman links to the "olive tree, ${ }^{, 402}$ the old order threatened by the new chaos.

Yeats' prayer for his daughter has been criticized by feminists for its reactionary values, ${ }^{403}$ just as Western feminists have criticized traditional cultures for values that reinforce women's subordination. ${ }^{404}$ Recall, however, that Yeats is writing about an infant, threatened by a "haystack- and roof-leveling wind." 405 Like human rights lawyers, he is trying to protect the most vulnerable. ${ }^{406}$ Like them, he is all too aware of the dangers awaiting her as a woman in a society at once traditional and in transition. ${ }^{407}$

Yeats refuses, however, to essentialize women, showing instead a rare awareness of their complexity and range. He speaks for women in a thousand voices, ${ }^{408}$ even alluding in his

humanity, but are such little, superficial, similarities as cherishing our parents and our children ...." Rorty, supra note 94, at 129.

402. See supra Part II.A.2.a.

403. As Joyce Carol Oates complains, "YYeats] would have his daughter an object in nature for others'-which is to say male-delectation. She is not even an animal or a bird in his imagination, but a vegetable: immobile, unthinking, placid, 'hidden,' ... the poet's daughter is to be brainless and voiceless, rooted." CULLINGFORD, supra note 1, at 137 (quoting Joyce Carol Oates, "At Least I Have Made a Woman of Her": Images of Women in Twentieth-Century Literature, 37 GA. REv. 17 (1983)). But see id. at 9 ("The father of 'A Prayer for my Daughter' urges a quiet life and a good marriage, but Yeats was delighted when [his daughter] started designing sets for the Abbey Theater").

404. See, e.g., Nussbaum \& Sen, supra note 32, at 4 ("[M]ost traditions contain elements of injustice and oppression, often deeply rooted; and it is frequently hard to find a basis for criticism for these inequities without thinking about human functioning in a more critical and universal way.").

405. A Prayer for my Daughter, supra note 1, at 403 . Yeats is concerned not only that his daughter will be harmed by the "postwar political chaos evoked in the drafts of the poem, but also by the model of femininity offered by the type of woman who raises her voice in the service of "opinions." CULLINGFORD, supra note 1 , at 132 .

406. Already a well-established poet, he hopes that his daughter will similarly move in privileged circles: "And may her bridegroom bring her to a house/Where all's accustomed, ceremonious." A Prayer for my Daughter, supra note 1 , at 405 .

407. See Elizabeth Butler Cullingford, Yeats and Women: Michael Robartes and the Dancer, in YEATS AND WOMEN, supra note 1, at 242 ("The central subject in Yeats's mind is his daughter's sexual identity. He makes a direct transition from the child asleep in the cradle to the woman in front of her looking glass: the intervening years of childhood innocence are ignored.").

408. As one critic observes, "Yeats's feminine masks are stunning in their range." Janis Tedesco Haswell, PRESSEd AGAinst DIVINITY: W.B. YEATS'S FEMININE MASKS 5 (1997). Thus, Yeats recognizes-and celebrates-the absence of consensual belief regarding gender. Cf. HUYSSEN, supra note 19, at 182 (referring to Yeats's The Second Coming, "It may be that some rough beast will slouch again toward Bethlehem, its haunches bloody, its name echoing in our ears with the din 
later work to the "woman in me."409 Indeed, it is in his "woman's voice" that he most wholeheartedly embraces complexity in the breathtaking "Crazy Jane" series written near the end of his life. ${ }^{410}$ Crazy Jane is a crone, a poor woman who somehow gets by, a defiant outsider who challenges her culture-she is a subversive ${ }^{411}$ and a storyteller. ${ }^{412}$ In a series of exchanges with the Bishop, Crazy Jane scoffs at his promise of a "heavenly mansion" should she mend her ways. Like Nietzsche $\mathrm{H}^{413}$ and Adorno, she is deeply suspicious of lofty abstractions, and the motives of those who espouse them. Rather, she insists:

Fair and foul are near of kin,

And fair needs foul,' I cried.

My friends are gone, but that's a truth

Nor grave nor bed denied,

Learned in bodily lowliness

And in the heart's pride.

But Love has pitched his mansion in

The place of excrement;

For nothing can be sole or whole

That has not been rent. ${ }^{\mathbf{4 1 4}}$

Those who seek to "make the world better for women"415 already recognize, like the classic human rights lawyers and like Yeats in A Prayer for my Daughter, 416 that the vulnerable must be protected. If they hope to further their project, however, they must also recognize, like the postmodernists and like Yeats in his Crazy Jane series, that women are remarkably diverse and should be allowed to speak for themselves. Like Crazy Jane, they should regard with skepticism any philosophy that denies its own dark

of history . . . all the evasions of our knowledge and actions thrive on the absence of consensual belief, an absence that also energizes our tempers, our wills. This is our postmodern condition.").

409. HASWELL, supra note 408, at 9. "[O]ne is not born a man, one becomes one; and Yeats had considerable trouble becoming a man." CullingFord, supra note 1, at 5. See also HUYSSEN, supra note 19, at 46 (explaining how a male author can assume a feminine persona: "The male, after all, can easily deny his own subjectivity for the benefit of a higher aesthetic goal, as long as he can take it for granted on an experiential level in everyday life.").

410. See generally HASWELL, supra note 408, at 5 .

411. See supra Part IV.B.1.

412. See supra Part IV.B.2. "Her opening poem, Crazy Jane and the Bishop, is a female curse against patriarchal ecclesiastical authority." Crazy Jane and the Irish Episcopate in CULLINGFORD, supra note 1 at 227, 235 .

413. Yeats began to read Nietzsche in 1902. KLINE, supra note 98 , at 35 .

414. Crazy Jane talks with the Bishop, in VARIORUM EDITION, supra note 1, at 512,513 .

415. Gagnier, supra note 385 , at 24.

416. See supra note 399 and accompanying text. 
side, its own "will to power," and carefully scrutinize the consequences of "free market democracy"-and its conspicuously partial appropriation of human rights rhetoric ${ }^{417}$-for particular women in particular contexts. Like Yeats, they should recognize the echoes of colonial discourse in gender discourse. ${ }^{418}$ Finally, like Crazy Jane, they should emphatically repudiate the characterization of marginalized women as Other, whether demonized or simply extraneous.

417. See supra Part III.A.2.

418. As Cullingford observes, "Colonial discourse had long bestialized the Irish as pigs . . . . While the Bishop mimics colonialist denigration of the Irish peasantry, ... Crazy Jane affirms the vital energies of the foul sty. ${ }^{m}$ CuLlingFoRD, supra note 1, at 242. See Berman, supra note 281, at 1528-29 (giving examples of "moments" in which "an international community' discovered its own identity by differentiating itself from an Other"). 
